\title{
Are the Asia and Pacific Small States Different from Other Small States?
}

Patrizia Tumbarello, Ezequiel Cabezon, and Yiqun Wu 


\title{
IMF Working Paper
}

Asia and Pacific Department

\section{Are the Asia and Pacific Small States Different from the Other Small States? Prepared by Patrizia Tumbarello, Ezequiel Cabezon, and Yiqun $\mathrm{Wu}^{1}$}

\author{
Authorized for distribution by Hoe Ee Khor
}

May 2013

\section{This Working Paper should not be reported as representing the views of the IMF.} The views expressed in this Working Paper are those of the author(s) and do not necessarily represent those of the IMF or IMF policy. Working Papers describe research in progress by the author(s) and are published to elicit comments and to further debate.

\begin{abstract}
The small states of the Asia and Pacific region face unique challenges in raising their growth potential and living standards relative to other small states due to their small populations, geographical isolation and dispersion, narrow export and production bases, exposure to shocks, and heavy reliance on aid. Higher fixed government costs, low access to credit by the private sector, and capacity constraints are also key challenges. The econometric analysis confirms that the Pacific Island Countries (PICs) have underperformed relative to their peers over the last 20 years. Although these countries often face more limited policy tools, policies do matter and can further help build resilience and raise potential growth, as evidenced in the recent business cycle. The Asia and Pacific small states should continue rebuilding buffers and improve the composition of public spending in order to foster inclusive growth. Regional solutions should also continue to be pursued.
\end{abstract}

JEL Classification Numbers: F15, F41, F42, F43, F47

Keywords: Asia and Pacific; small states; micro states, Pacific islands, growth, volatility Authors' E-Mail Address: ptumbarello@imf.org; ecabezon@imf.org; ywu2@imf.org

\footnotetext{
${ }^{1}$ The authors would like to thank Peter Allum, Luis Breuer, Ian Davidoff, Sergei Dodzin, Romain Duval, Tubagus Feridhanusetyawan, Craig Fookes, Leni Hunter, Sonali Jain-Chandra, Fazurin Jamaludin, Nghi Luu, Koshy Mathai, Vance Martin, Brad McDonald, Shanaka Peiris, Alexander Pitt, Jack Ree, Neil Saker, Werner Schule, Niamh Sheridan, Shiu Singh, Olaf Unteroberdoerster, Yongzheng Yang, Akihiko Yoshida, the participants of the Small Islands Club at the IMF for their comments, and Hoe Ee Khor for his guidance throughout the project. Shari Boyce provided excellent editorial assistance.
} 


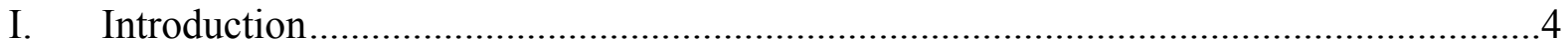

II. Characteristics of Small States in the Asia and Pacific Region.......................................

III. Managing Shocks, Vulnerability, and Volatility .........................................................11
A. Shocks
B. Vulnerability
C. Volatility

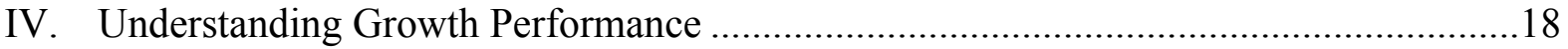

A. Econometric Analysis: Growth Determinants in the Asia and Pacific Small States ...20

Boxes

1. Special Challenges Facing Pacific Islands Micro States ................................................18

Figures

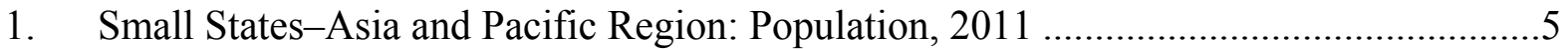

2. Small States-Asia and Pacific Region: Distance to the Closest Continent .......................5

3 Small States-Asia and Pacific Region: Liner Shipping Connectivity Index .....................6

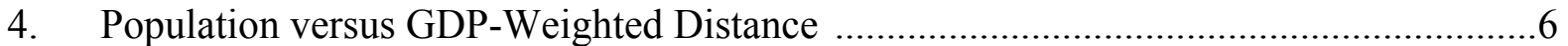

5. Small States-Asia and Pacific Region: Current Government Expenditure, 2011 ............6

6. Small States-Asia and Pacific Region: Cost of Government, 1990-2010 ………...........7

7. Small States: Trade Openness................................................................................

8. Small States-Asia and Pacific Region: Trade Openness ...............................................8

9. Small States-Asia and Pacific Region: Interest Rate Spread of Commercial Banks .......8

10. Small States-Asia and Pacific Region: Domestic Credit to Private Sector.......................8

11. Small States-Asia and Pacific Region: Financial Development and Inequality,

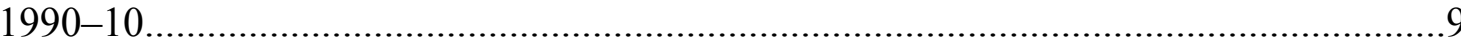

12. Small States-Asia and Pacific Region: Real per Capita GDP Growth and Business

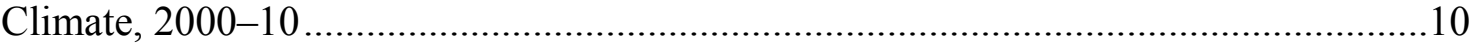

13. Small States-Asia and Pacific Region: Ease of Doing Business Index..........................10

14. Small States-Asia and Pacific Region: Secondary School Enrollment...........................11

15. Selected Asia and Pacific Countries: Lowest Human Development Index (HDI) Rank, 2011

16. Small States-Asia and Pacific Region: Tourism and Remittances...............................12

17. Small States-Asia and Pacific Region: Sovereign and Investment Fund Balances .......12

18. Small States-Asia and Pacific Region: Official Development Aid by OECD Donors ..12

19. Small States-Asia and Pacific Region: Official Development Assistance by Donors ...12

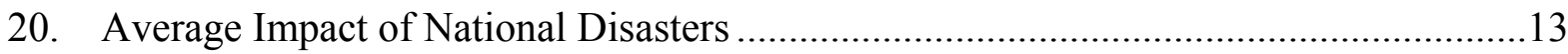

21. Small States-Frequencies of Shocks .......................................................................13

22. Small States-Asia and Pacific Region: External Grants, 2011......................................13 
23. Small States-Asia and Pacific Region: Trade Balance of Goods and Services .............13

24. Small States-Asia and Pacific Region: Current Accounts Excluding Grants ...............14

25. Small States-Asia and Pacific Region: Public Debt, 2011 ........................................14

26. Small States-Asia and Pacific Region: Volatility of Real per Capita GDP Growth, 1990-2010.

27. Small States-Asia and Pacific Region: Real per Capita GDP Volatility and Growth, 1990-2010

28. Small States-Asia and Pacific Region: Volatility of Real per Capital GDP Growth and Governance, 1990-2010

29. Small States-Asia and Pacific Region: Volatility of GDP Growth, Terms of Trade, Aid,

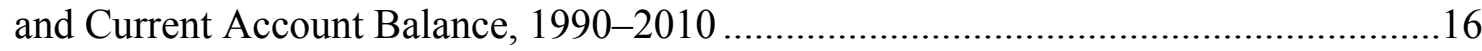

30. Small States-Asia and Pacific Region: Revenue Volatility .......................................16

31. Small States-Asia and Pacific Region: Fiscal Volatility, 1990-2010 .........................17

32. Small States-Asia and Pacific Region: Pro-cyclical Bias in Fiscal Policy, 2005-10 ....17

33. Small States: GDP per Capita, 2011 .........................................................................19

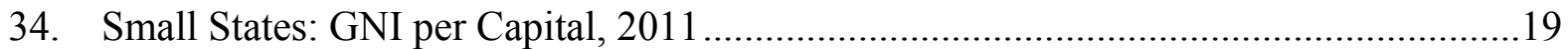

35. Small States-Asia and Pacific Region: Real GDP per Capita Growth.........................19

36. Small States-Asia and Pacific Region: Real GDP Growth, 1990-2012 .....................19

37. Small States-Asia and Pacific Region: Rebuilding Policy Buffers .............................21

Tables

1. Geographical Dispersion: Average Sea Distance between Two Inhabitants for the Same

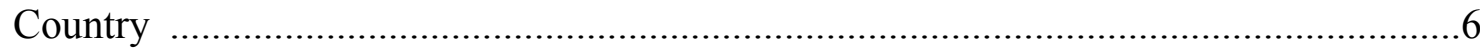

2. Small States-Asia and Pacific Region: Main Exports of Goods and Services................7

3. Small Pacific Island Countries: Interest and Non-interest Income of Commercial Banks,

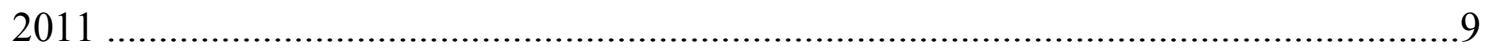

4. Determinants of Real per Capital GDP Growth …..............................................22

5. Pacific Island Countries: Growth Advantages and Disadvantages...............................23

6. Small States-Asia and Pacific Region: Growth Advantages and Disadvantages...........23

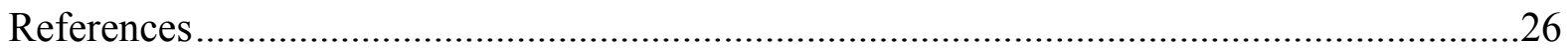

Appendix Table

Small States of the Asia and Pacific Region: Selected Indicators, 2012 


\section{INTRODUCTION}

The small states of the Asia and Pacific region face unique challenges in raising their growth potential and living standards. These countries are particularly vulnerable because of their small populations, geographical isolation and dispersion, narrow export and production bases, lack of economies of scale, limited access to international capital markets, exposure to shocks (including climate change), and heavy reliance on aid. In providing public services, they face higher fixed government costs relative to other states because public services must be provided regardless of their small population size. Low access to credit by the private sector is an impediment to inclusive growth. Capacity constraints are another key challenge. These challenges seem to be particularly acute in micro states (states with a population of less than 200,000 people). The small states of the Asia and Pacific region face higher volatility than other small states in several respects, specifically, per capita GDP growth, changes in the terms of trade, aid, current account balance, and revenue.

The econometric analysis confirms that the Pacific Island Countries (PICs) have underperformed relative to their peers over the last 20 years. After controlling for some standard variables that explain per capita GDP growth, PICs suffer a disadvantage in per capita GDP growth of about 2 percentage points, compared with an average small state.

The small states also face more limited policy tools. Five out of 13 countries do not have a central bank and the scope for diversifying their economies is narrow. Given their large development needs, fiscal policies have been, at times, pro-cyclical. Within the Asia-Pacific small states group, the micro states are subject to more vulnerability and macroeconomic volatility than the rest of the Asia-Pacific small states.

\section{But policies do matter and they can further help build resilience and raise potential} growth. Despite all these challenges, these countries have done slightly better than some comparators during the recent business cycle, thanks to sound policies and strong linkages with resilient economies in the region, and some small states in the region have made progress in building policy buffers. But growth rates have remained quite low. Going forward, given their high vulnerability to external shocks, these countries should continue rebuilding buffers and improve the composition of public spending with regard to education, health, and infrastructure in order to foster inclusive growth. The Asia and Pacific small states have enormous untapped marine resources and further effort is needed to properly exploit and manage them. Regional solutions should also continue to be pursued, mainly in fisheries, information technology, and aviation safety. Further integration with the Asia and Pacific region should help raise growth potential. 


\section{Characteristics of Small States in the Asia And Pacific Region}

\section{The small states of the Asia and Pacific region face unique challenges in raising their} growth potential and living standards. These challenges distinguish them from the broader group of small states across other regions. Even among them, heterogeneity is high, with the micro ${ }^{2}$ states subject to more vulnerability and macroeconomic volatility than the rest of the Asia-Pacific small states.

\section{The small states of the Asia and Pacific} region are remote, widely dispersed, and scarcely populated (Figure 1). They are geographically distant from their major markets and trading partners - unlike small islands in other regions. Remoteness raises transport costs and keeps these economies relatively isolated. Their large dispersion poses another challenge (Table 1). Most Pacific Island Countries (PICs) consist of hundreds of islands scattered over an area in the Pacific Ocean that occupies 15 percent of the globe's surface. Their small size and dispersion preclude the exploitation of geographical agglomeration effects. Two PICs are the smallest IMF members in terms of population-Tuvalu and Palau. PICs'

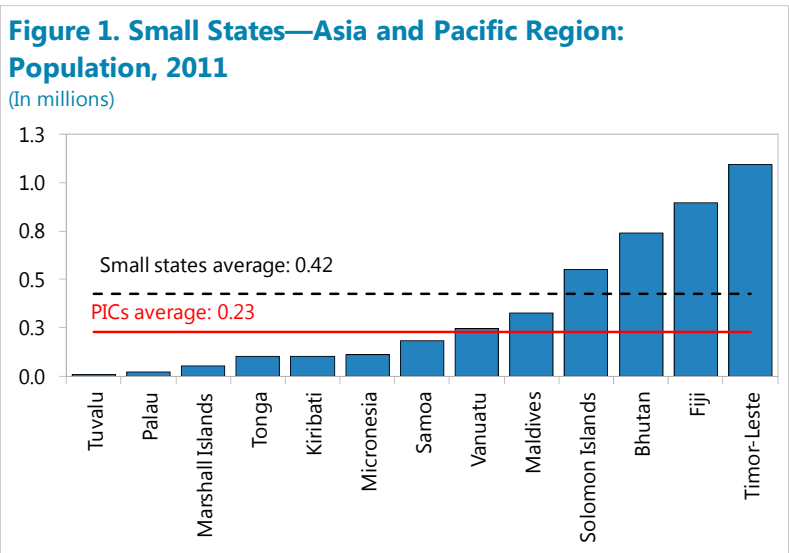

Sources: IMF, WEO; and World Bank, WDI.

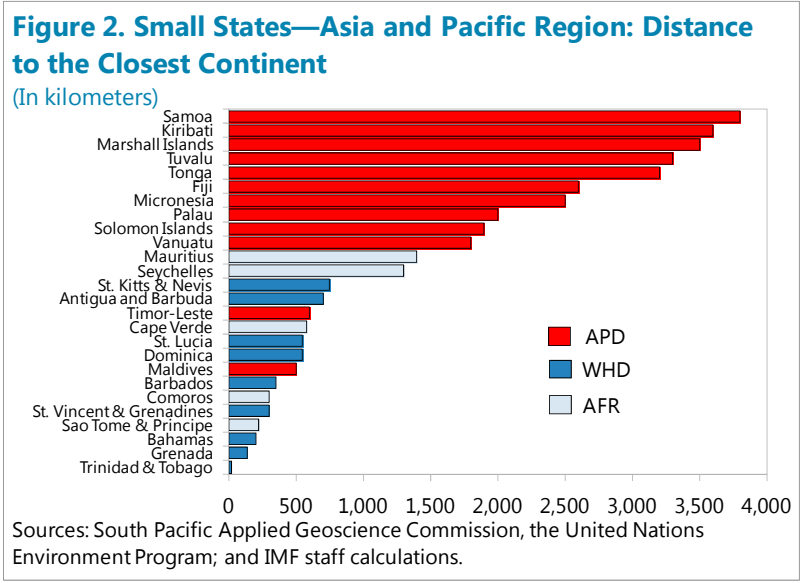
average population is half the average population of other small states outside the Pacific region. The Pacific Islands are by far the most remote countries in the world, according to different indicators: the United Nation's liner shipping connectivity index — which measures countries' connectedness to global shipping networks - based on the status of their maritime transport sector, and two different measures of distance (Figures 2-4).

\footnotetext{
2 This paper covers the Asia and Pacific developing (APD) small states. The group includes: Bhutan, Fiji, Kiribati, Maldives, Marshall Islands, Micronesia, Palau, Samoa, Solomon Islands, Timor-Leste, Tonga, Tuvalu, and Vanuatu. With the exception of Bhutan, Maldives, and Timor-Leste, they are all Pacific Island countries. The micro states (i.e., countries with 2011 populations below 200,000) include: Kiribati, Marshall Islands, Micronesia, Palau, Samoa, Tonga, and Tuvalu.
} 


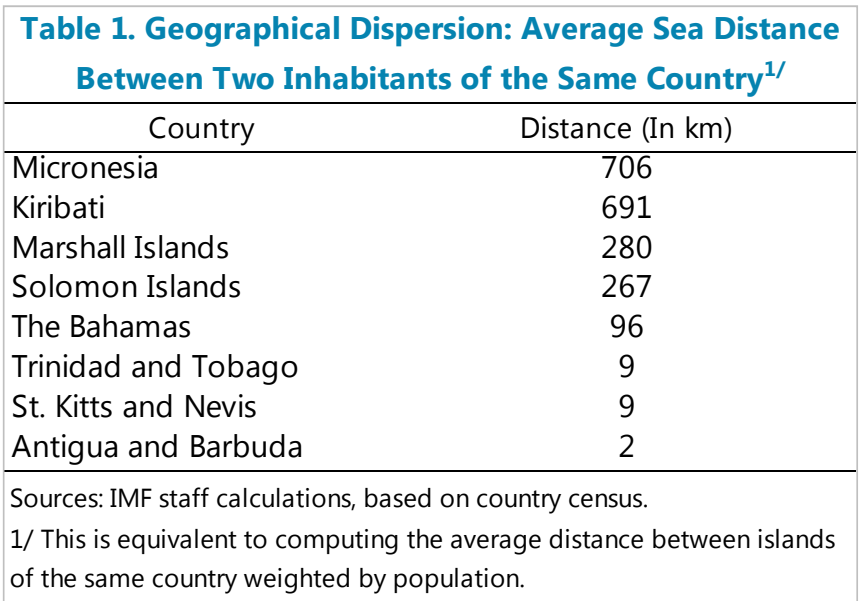

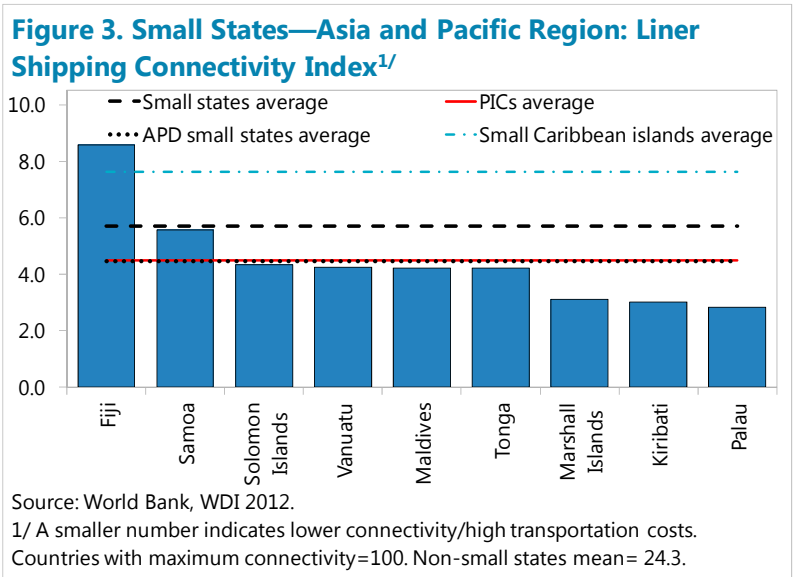

\section{In providing public services, the Asia and} Pacific small states face higher fixed (i.e., per capita) government costs relative to other small states (Figures 5 and 6). This is because public services must be provided regardless of the small population. In the island states, this effect is compounded by remoteness and large dispersion and it leads to an inverse relationship between the size of the country and the government. Large dispersion and smallness increase input costs and worsen the diseconomies of scale
Figure 4. Population versus GDP-Weighted Distance ${ }^{1 /}$ (In kilometers)

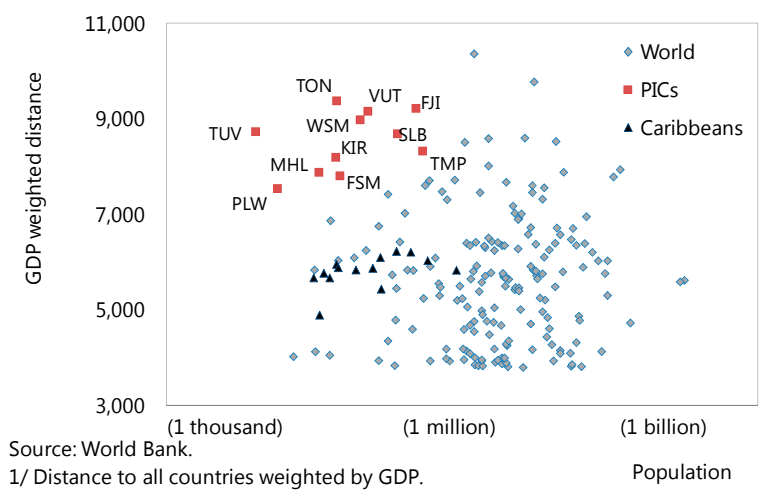

Figure 5. Small States-Asia and Pacific Region: Current Government Expenditure, 2011

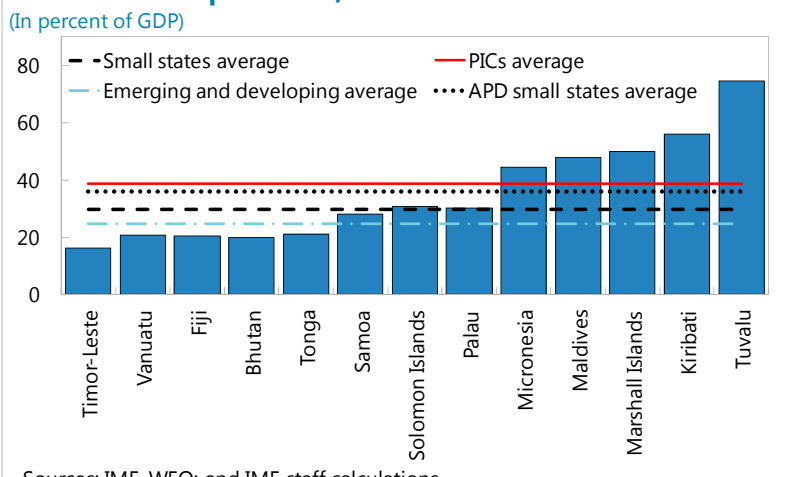

Sources: IMF, WEO; and IMF staff calculations. associated with small populations in providing such public goods and services as education, justice, social services, infrastructure, and in creating public institutions. Current government spending as a share of GDP is generally higher in the micro states than in all other groups. ${ }^{3}$

\footnotetext{
${ }^{3}$ See Becker (2012), on the importance of geographic isolation as a source of vulnerability and on the higher fixed costs of government in the Pacific islands.
} 
Figure 6. Small States—Asia and Pacific Region: Cost of Government, 1990-2010
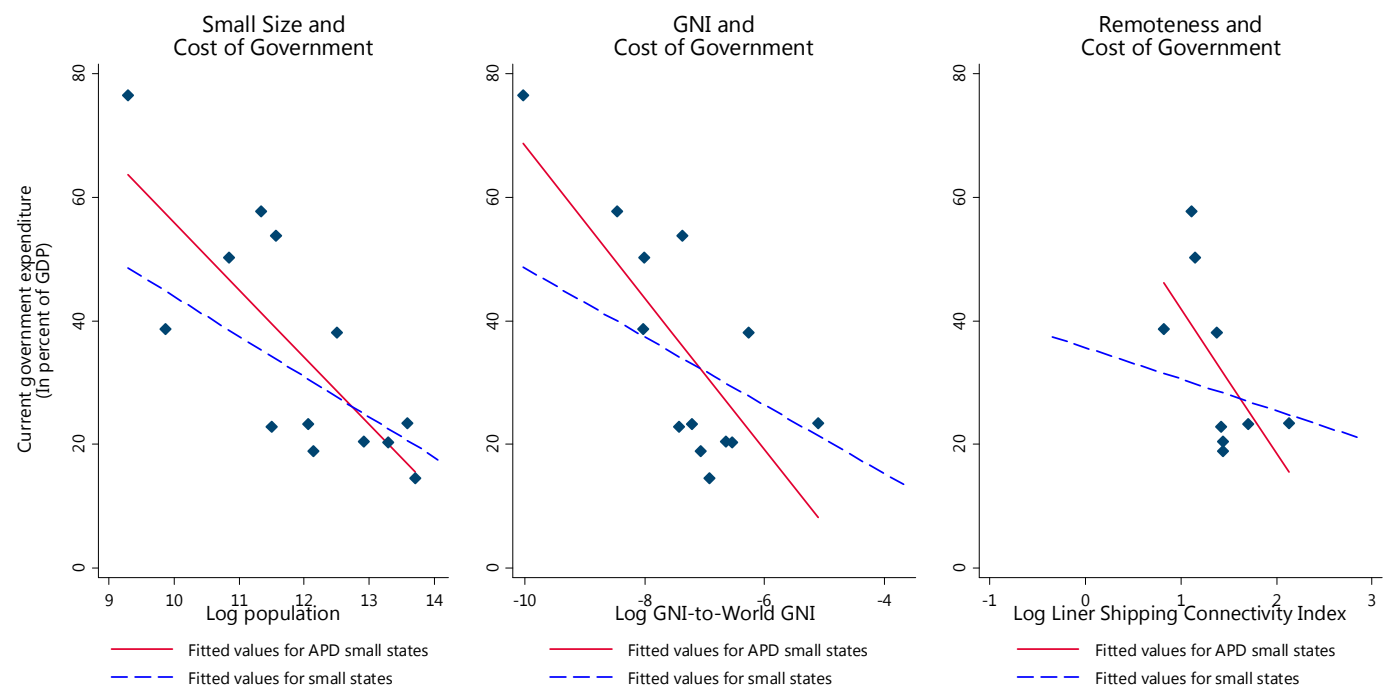

Sources: World Bank, WDI; IMF, WEO; and IMF staff calculations.

These countries are quite heterogeneous (Appendix, Table 1) but they all have narrow export and production bases. Some rely primarily on tourism (Maldives, Fiji, Samoa, Palau, and Vanuatu), and some on fishing (Kiribati, Marshall Islands, Micronesia, and Tuvalu) (Table 2). Some are commodity or energy-resource based (Bhutan, Solomon Islands, and Timor-Leste). While scope for export diversification remains limited, with the exception of Fiji and Samoa, niche or eco-tourism is gradually developing in Kiribati, Marshall Islands, and Micronesia. Recent experiences in setting up joint ventures for marine processing are also notable as ways to move up the value-added chain.

Table 2. Small States-Asia and Pacific Region: Main Exports of Goods and Services

\begin{tabular}{lcc}
\hline \multicolumn{1}{c}{ Country } & First good or service & Second good or service \\
\hline Bhutan & Hydroelectricity & Minerals \\
Maldives & Tourism & Coffee \\
Timor-Leste & Oil & Sugar \\
Pacific Island Countries & & Copra \\
Fiji & Tourism & Copra \\
Kiribati & Fish & Copra \\
Marshall Islands & Fish & Fish \\
Micronesia & Fish & Copra \\
Palau & Tourism & Gold \\
Samoa & Tourism & Tourism \\
Solomon Islands & Logs & Copra \\
Tonga & Agriculture (squash) & Copra \\
Tuvalu & Fish & Tourism \\
Vanuatu & &
\end{tabular}

Sources: IMF staff reports; and country authorities. 


\section{PICs appear to be less open than comparators but openness has increased recently}

(Figures 7 and 8). Less openness reflects their remoteness, their underdeveloped infrastructure (which hurts tourism), and low competitiveness. Poor connectivity and high transport costs have prevented greater trade integration with the rest of the region. Trade openness has increased over time and integration has benefitted the Asia and Pacific small states, but it has also posed challenges because shocks are transmitted more rapidly in a more interconnected world.
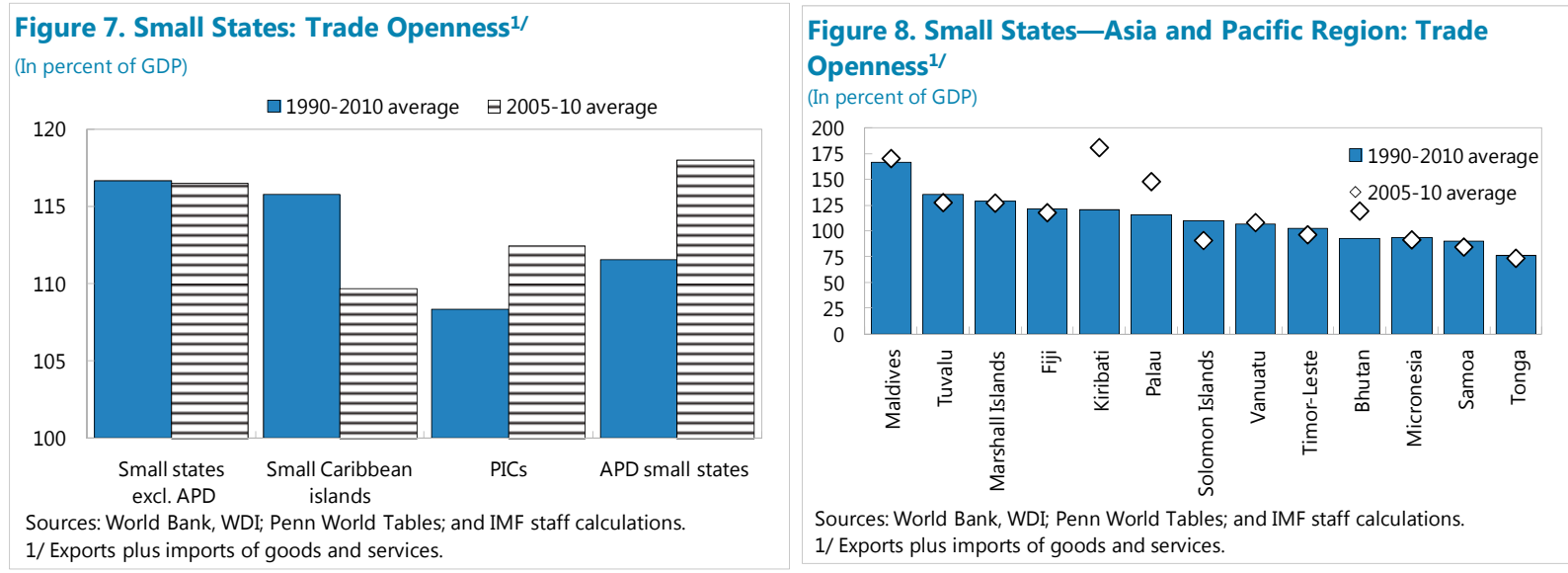

Financial depth is generally below that of other small states (Figures 9 and 10). Access to credit is more limited than in other small states. And in the Pacific Islands, land tenurecommunal land - is a constraint on credit growth and private sector development, leading to less inclusive growth. In most Pacific Islands, land is owned by the government and by large families, rather than by individuals. Family tenure makes property rights unclear and limits the ability to use land as collateral. If banks are unable to effectively secure their lending with land as collateral, lending becomes costly. The spread between lending and borrowing rates is very high in the Pacific Islands.
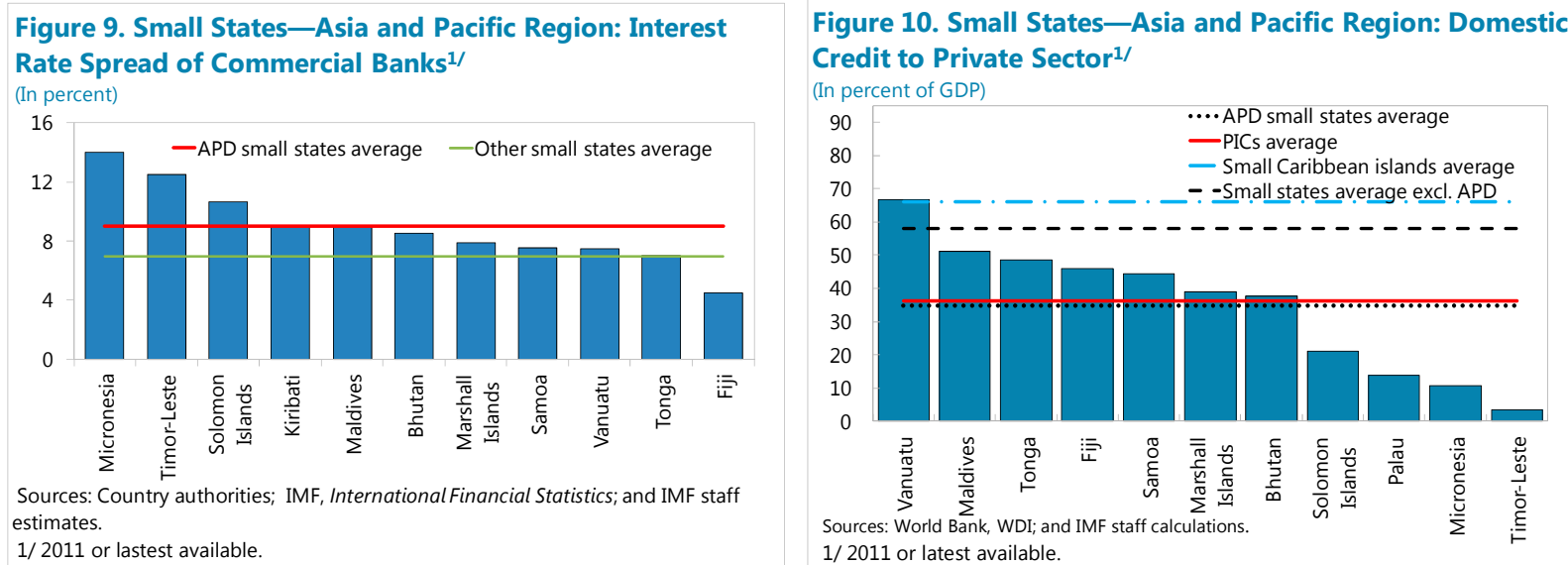

Yet, commercial banks in the Pacific Islands — mainly foreign banks - are well capitalized and highly profitable, despite the relatively low lending growth of recent 
years. This reflects continued high levels of non-interest income, largely from foreign exchange activities and from fees and charges - which are higher than some comparators (Table 3). ${ }^{4}$

Table 3. Small Pacific Island Countries: Interest and Non-interest Income of Commercial Banks, 2011

\begin{tabular}{lcc}
\hline & $\begin{array}{c}\text { Net interest income } \\
\text { (percent of total assets) }\end{array}$ & $\begin{array}{c}\text { Non-interest income } \\
\text { (percent of total assets) }\end{array}$ \\
\hline Fiji & 3.6 & 3.0 \\
Marshall Islands & 12.9 & 1.3 \\
Palau & 15.5 & 1.2 \\
Samoa & 6.0 & 4.0 \\
Solomon Islands & 5.2 & 6.2 \\
Tonga & 5.1 & 4.8 \\
Vanuatu & 4.0 & 3.2 \\
Memorandum items: & & \\
Australia & 1.8 & 0.9 \\
Antigua and Barbuda & 4.6 & 4.3 \\
Bahamas & 5.5 & 0.3 \\
Grenada & 4.4 & 4.2 \\
St. Kitts and Nevis & 1.9 & 5.9 \\
St. Lucia & 3.8 & 4.7 \\
St. Vincent and the Grenadines & 3.9 & 4.7 \\
Suriname & 1.4 & 0.6 \\
Cape Verde & 3.7 & 1.1 \\
Mauritius & 2.0 & 1.0 \\
Seychelles & 3.1 & 2.9 \\
PICs (average) & 7.5 & 3.4 \\
Small Caribbean states (average) & 3.6 & 3.5 \\
Small African states (average) & 2.9 & 1.7 \\
\hline Sources: Davies and Vaught, 2011; and Central Bank data. & & \\
& & \\
& & \\
& &
\end{tabular}

Low access to credit by the private sector is an impediment to inclusive growth

(Figure 11). Indeed, a simple regression suggests a negative relationship between inequality (proxied by the Gini coefficient) and the share of private credit as a percent of GDP. Fostering financial inclusion by increasing the use of mobile phone networks for basic financial services is a recent positive development in the small Pacific states (i.e., Fiji, Samoa, Solomon Islands, and Tonga) to support private sector growth. The decreasing cost of sending remittances to the Pacific by Australian banks is also helping foster financial sector intermediation.

Figure 11. Small States-Asia and Pacific Region: Financial Development and Inequality, 1990-2010

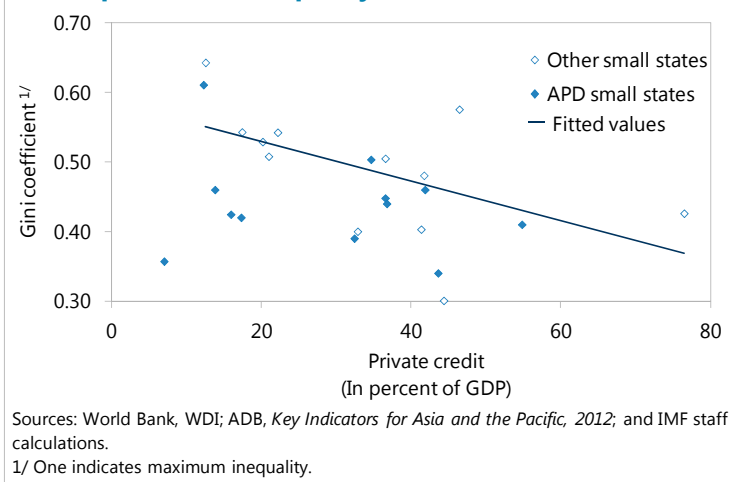

\footnotetext{
${ }^{4}$ Davies and Vaught (2011).
} 
International market access is also very limited. Because of capacity and structural impediments, including legal and administrative frameworks, the Pacific Islands have still not been able to tap international capital markets and attract capital inflows. Their market access to private capital flows is almost nonexistent, excluding Fiji and Maldives.

\section{Indicators on business environment are weaker in the Asia and Pacific small states than} in some comparators. According to the latest World Bank Doing Business Report, procedures for starting and closing a business are more expensive in the small Pacific islands than in the other Asia and Pacific small states as well as in the Caribbean island countries. Weak private sector development impedes sustainable growth (Figures 12 and 13).
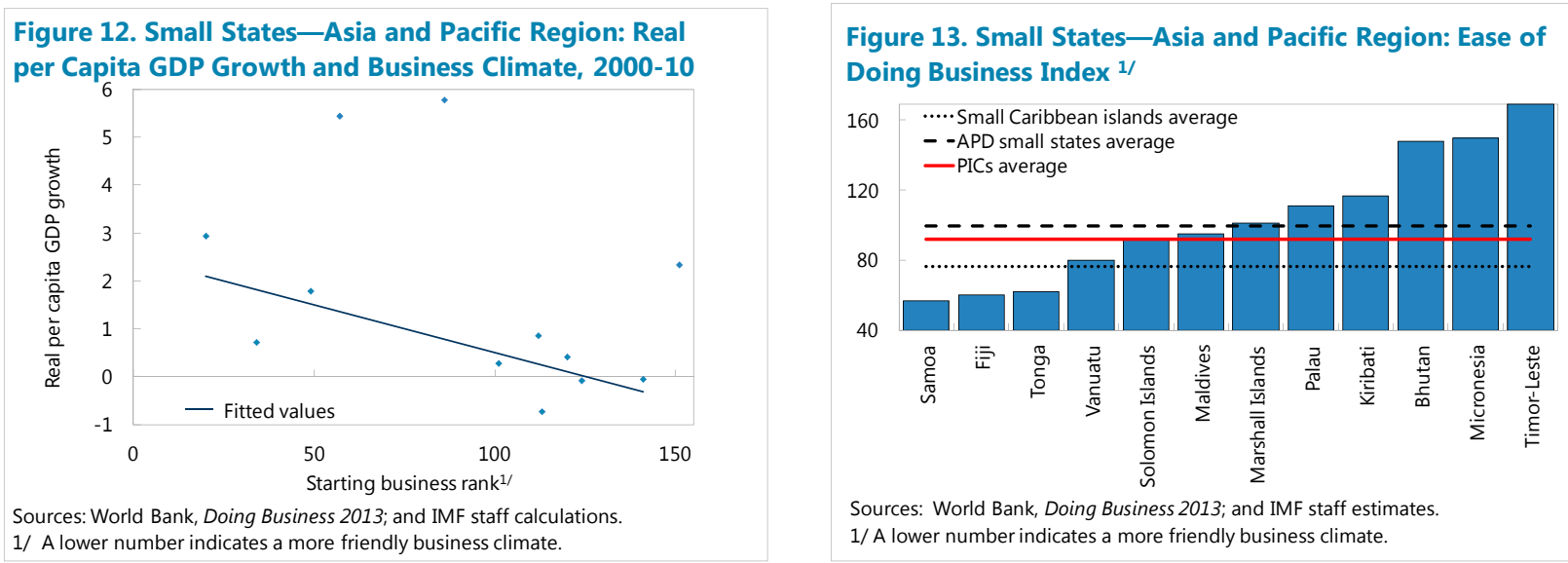

Policy tools are also limited. Five out of 13 countries do not have a central bank (Kiribati, Marshall Islands, Micronesia, Palau, and Tuvalu). The Australian dollar circulates as legal tender in Kiribati and Tuvalu, and the U.S. dollar in Marshall Islands, Micronesia, and Palau. The use of dollarization or of fixed/managed exchange rate regimes for the other AsiaPacific small states reflects the fixed costs of operating an independent monetary policy as well as weak monetary transmission mechanisms. The latter is largely the result of structural characteristics of financial markets (e.g., shallow money markets, the absence of such institutions as credit bureaus that facilitate bank lending, and small market size) ${ }^{5}$

Capacity constraints are another key challenge. These constraints are larger in the PICs relative to their comparators. For example, school enrollment is lower than in other small states (Figure 14). A recent analysis ${ }^{6}$ suggests that in the small PICs capacity constraints within the public service are associated with small size and explain the underperformance on public financial management reforms. These constraints represent another impediment to raising growth potential. That said, Solomon Islands has recently taken commendable steps

\footnotetext{
${ }^{5}$ Yang and others (2011).

${ }^{6}$ Haque and others (2012).
} 
to strengthen public finance management and promote budget transparency and accountability, as have Fiji and Vanuatu.

Human development indicators are among the lowest in the region (Figure 15). In the Asia and Pacific region, of the 12 countries with the lowest rank on the human development index, 6 are small states, and 3 are micro states.
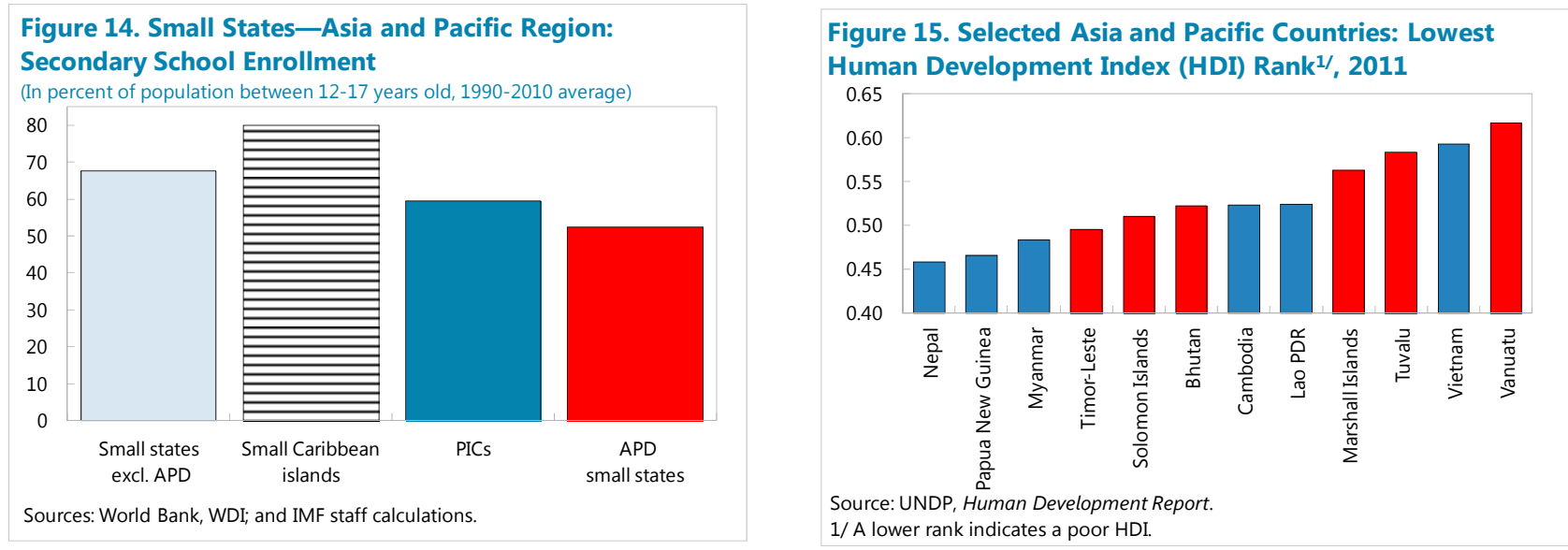

III. Managing Shocks, Vulnerability, and Volatility

A. Shocks

Small states in the Asia and Pacific region are heavily exposed to shocks. Some shocks are related to external developments, some to weather and environmental events, and some are home grown, such as political shocks.

The main channels of spillover from a global downturn are the terms of trade, remittances, tourist flows, and the financial channels.

- All PICs remain especially vulnerable to global commodity price shocks-particularly for food and fuel, given their large share in total imports (about 50 percent). In light of the rise in commodity prices and their greater volatility in recent years, terms-of-trade shocks have translated into large output shocks. ${ }^{7}$ Higher import prices have also raised production costs and reduced real household income.

- External demand and financial shocks are also important. The main channels of contagion are changes in remittances (in Samoa, Tonga, Tuvalu, and, to a lesser extent, Fiji) and tourism receipts (in Maldives, Palau, Vanuatu, Samoa, and Fiji) (Figure 16). A fall in stock prices in the advanced economies would also affect PICs with large trust

\footnotetext{
${ }^{7}$ See Sheridan, Tumbarello, and $\mathrm{Wu}$ (2012), for an assessment of the impact of external shocks from global and regional economies on the PICs.
} 
funds whose assets are invested offshore (Kiribati, Marshall Islands, Micronesia, Palau, and Tuvalu), as occurred during 2008-09 (Figure 17).

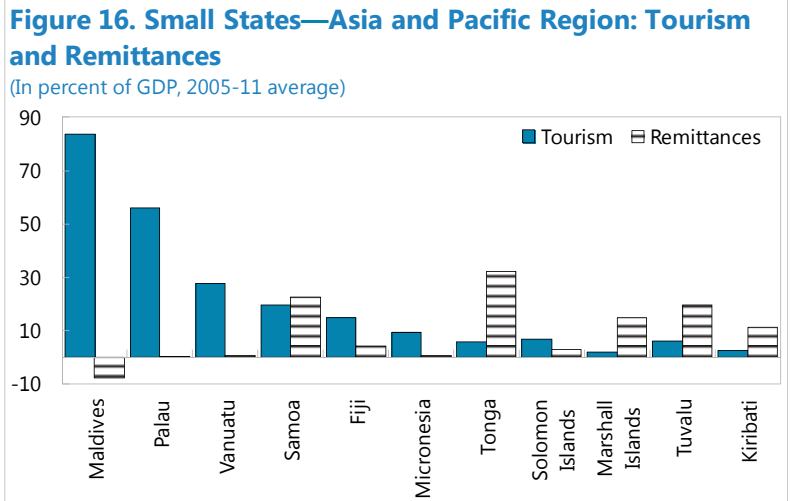

Sources: Country authorities; and IMF staff calculations.

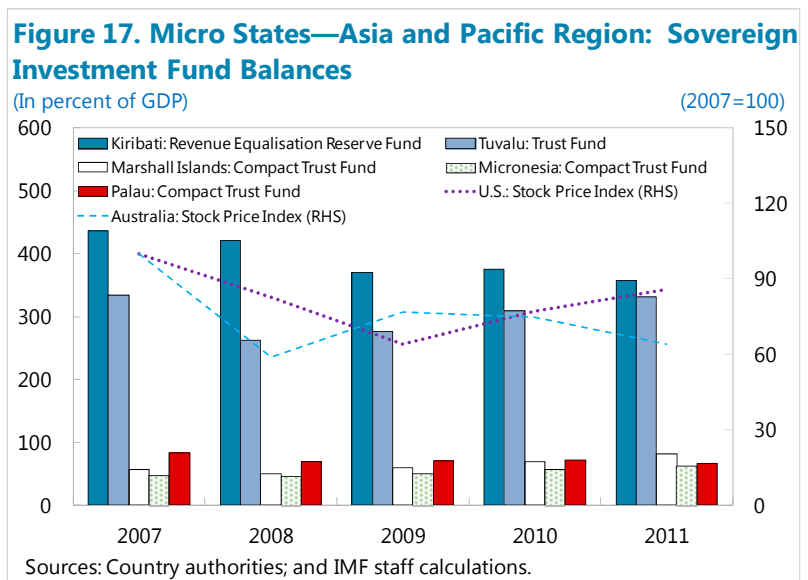

Aid flows have proven resilient, as the main donor in the region, Australia (Figure 18) weathered the global financial crisis relatively well. While aid flows from Australia and New Zealand are expected to hold up, weaker-than-expected economic activity in these countries could hit the PICs particularly hard, as both of these countries are also their main trade partners. Aid from the United States has a large impact on three Pacific Island countries (Marshall Islands, Micronesia, and Palau) that have signed the bilateral Compact of Free Association agreement with the United States (Figure 19). This aid represents over 65 percent of total aid in Palau and 90 percent of total aid in Marshall Islands and Micronesia. These PICs finance a large portion of their budgetary and balance of payments needs with "Compact grants," which are, however, scheduled to expire in the 2023/24 fiscal year.
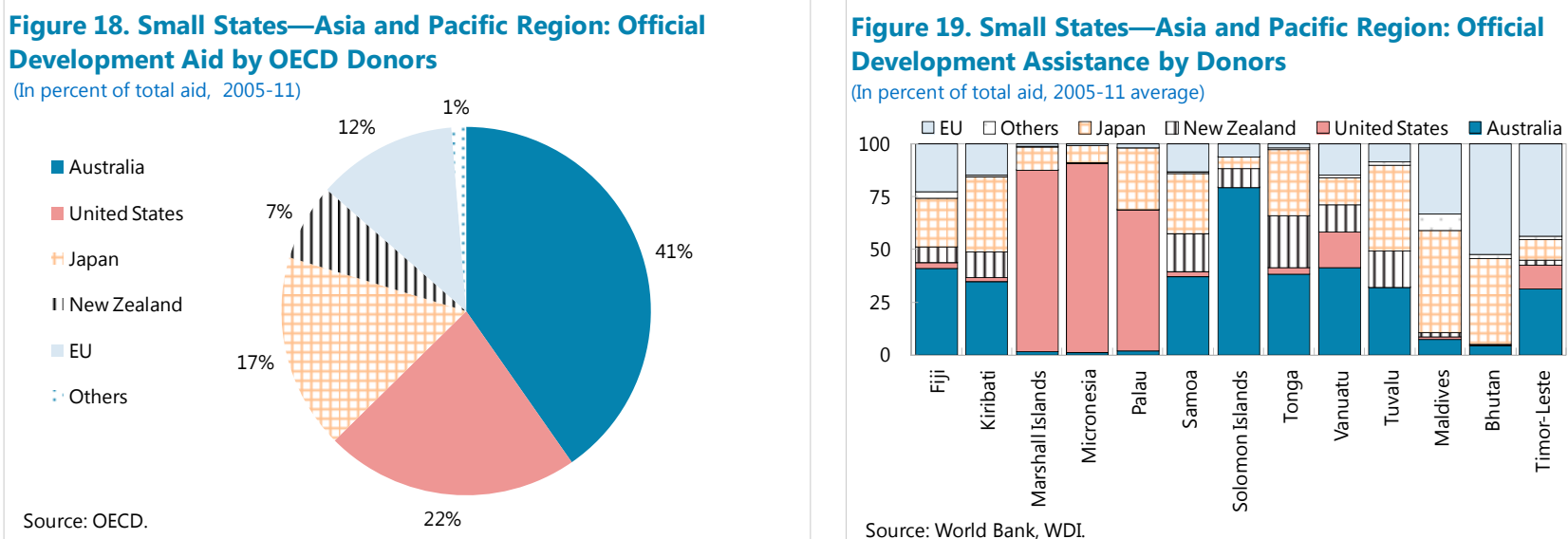

PICs are also severely affected by natural disasters and climate change (Figure 20). According to a 2012 World Bank Report, Acting Today for Tomorrow, of the 20 countries in the world with the highest average annual disaster losses measured by GDP, 8 are PICs: Vanuatu, Niue, Tonga, Micronesia, Solomon Islands, Fiji, Marshall Islands, and the Cook Islands. Several small island countries in the Asia and Pacific region are low-lying coral islands, with their population and infrastructure concentrated along the coast (Kiribati, 
Maldives, Marshall Islands, and Tuvalu). This makes them highly vulnerable to the effects of such climate change as sea-level rise and coastal erosion. While worldwide databases are available to account for the costs of natural disasters, the costs of climate change (including the fiscal costs), which are substantial in the Asia and Pacific small states, remain largely unestimated.

\section{The frequency of shocks is also higher in the small Pacific Islands than in other} comparators (Figure 21). Our event analysis shows that political, terms-of-trade, and natural disaster shocks are more frequent relative to other low-income small states.

\section{B. Vulnerability}

\section{Reliance on aid and remittances to finance structural trade deficits remains a key vulnerability (Figures 22 to 24). Small} domestic markets coupled in most cases with poor resource endowments result in large trade

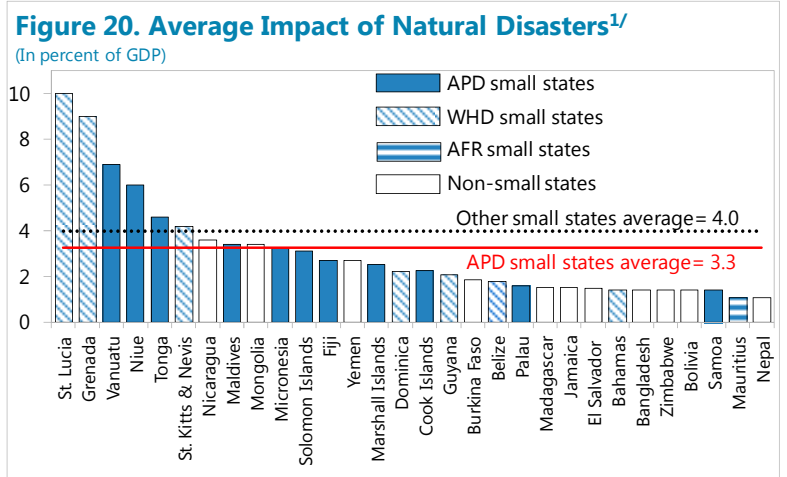

Source: World Bank and United Nations, Natural Hazards, UnNatural Disasters: The Economics of Effective Prevention, 2012.

1 / Excludes the cost of climate change.

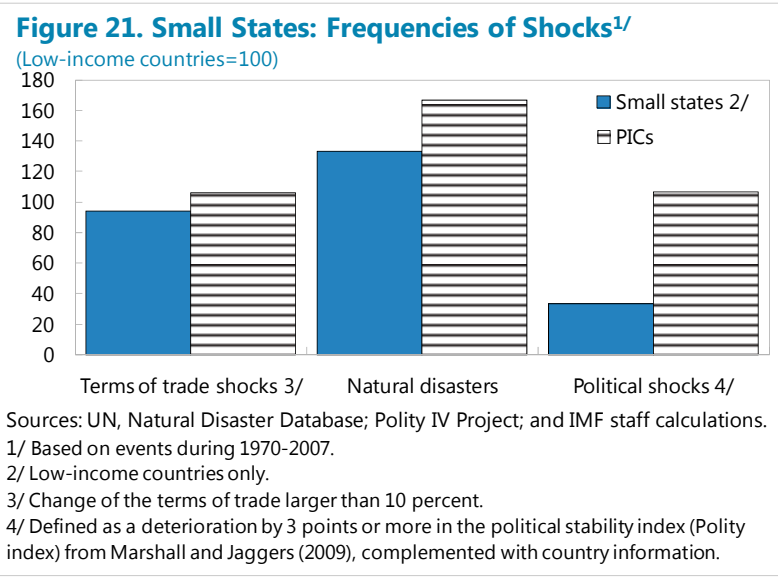
deficits. The Asia-Pacific small states rely heavily on imports; most are net importers of energy and food, given the shortage of arable land. They also import capital goods because of their dependence on imported technologies and other consumer goods.

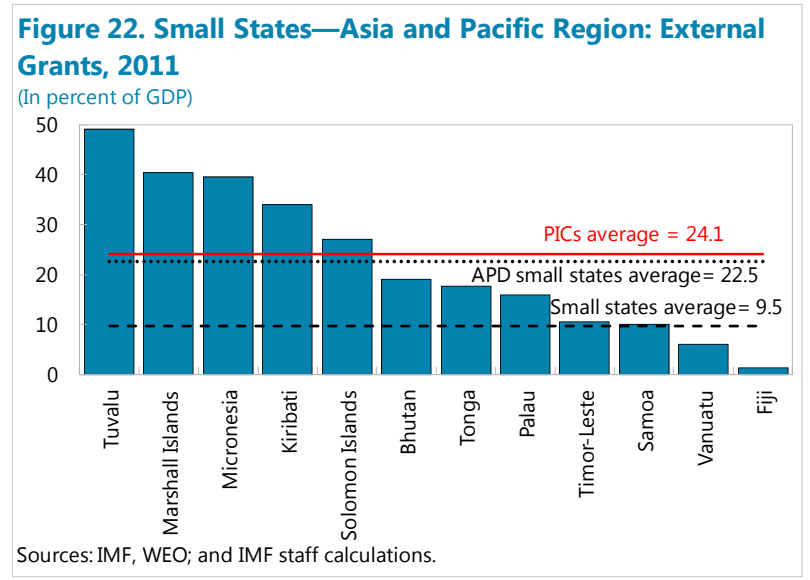

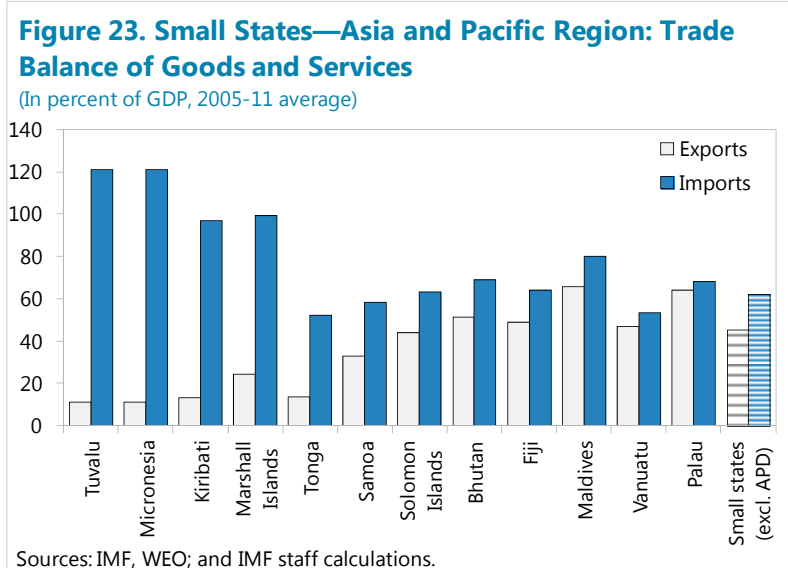

Sources: IMF, WEO; and IMF staff calculations. 

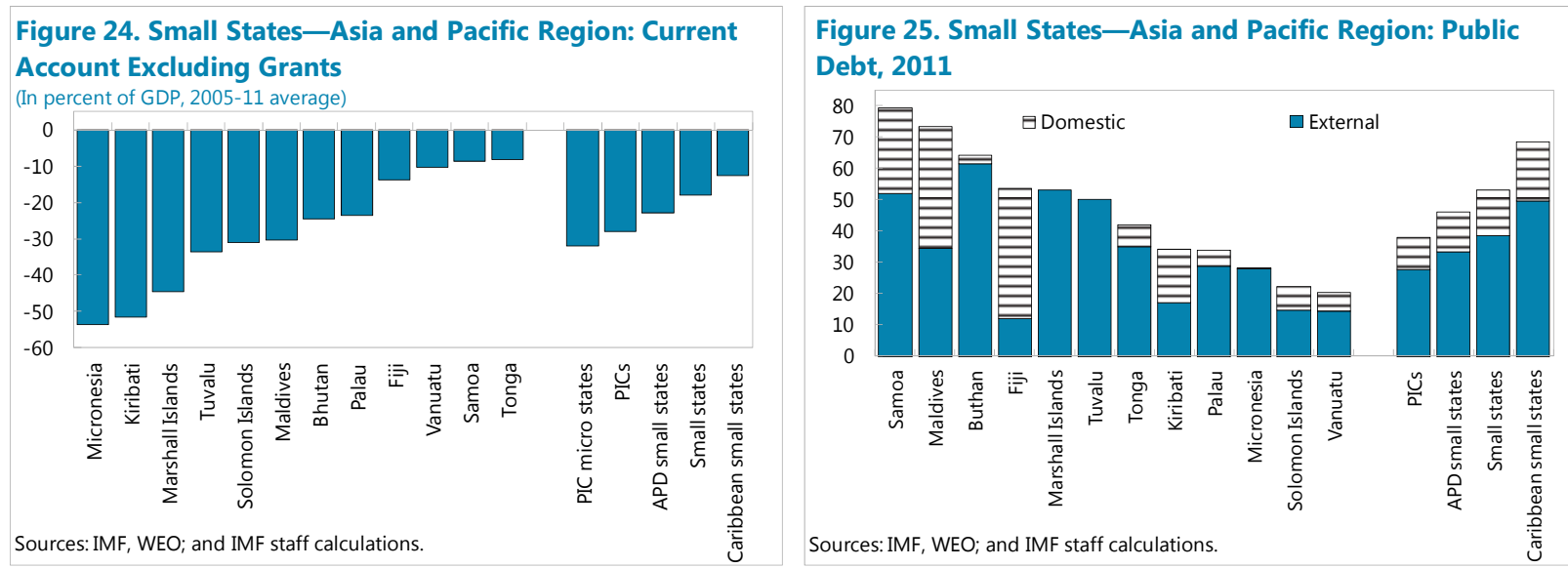

Owing to large official development assistance (ODA) flows, debt levels have remained in check for most countries until recent years (Figure 25). But since the 2008-09 crisis, debt has increased, in part because of the need for countercyclical fiscal support and partly because of new borrowing from Asian emerging markets. Fiscal space is currently limited for Asia and Pacific small states with high public debt, which narrows the scope for countercyclical policies should the economies weaken. As of February 2013, based on the latest published Article IV staff reports, four Asia-Pacific small states were at high risk of debt distress (Kiribati, Maldives, Tonga, and Tuvalu), according to the low-income countries debt sustainability analysis; three were at moderate risk of debt distress (Bhutan, Samoa, and Solomon Islands); and two at low risk of debt distress (Fiji and Vanuatu).

Different indices of vulnerability to shocks have been developed in the literature. The Becker index (2012) provides a vulnerability ranking based on different dimensions of vulnerability (e.g., small population, volume of arable land, and distance). The analysis also shows that using GNI per capita to determining the income status of small states can be misleading when the population is very small and dispersed. This is because a much higher proportion of income in micro states covers fixed costs of government, such as the costs of establishing institutions and providing public services, especially in countries composed of scattered islands. Therefore, per capita indicators tend to overstate the economic conditions of micro states. Because of the high fixed costs and distance from the rest of the world, these states' effective purchasing power is actually quite low despite a not-so-low GNI per capita. Similar vulnerability indices have been developed by Briguglio (1995) and the Commonwealth Secretariat (2000).

\section{Volatility}

The small states of the Asia and Pacific region face higher volatility than other small states in several respects, specifically, per capita GDP growth, changes in the terms of trade, aid, current account balance, and revenue.

- GDP per capita (Figures 26, 27, and 28). During 1990-2010, the volatility of GDP per capita was higher in Asia and Pacific small states than in other small states - especially the micro states, which are all PICs. Tuvalu experienced the highest variability among the 
PICs, while Timor-Leste and Maldives faced higher GDP volatility than other small Asian states. Consistent with the literature on the negative impact of output volatility on growth, higher output volatility was associated with lower economic growth during 1990-2010 in the Asia-Pacific small states and a lower quality of governance, after controlling for other variables.

\section{Figure 26. Small States-Asia and Pacific Region: Volatility of Real per Capita GDP Growth, 1990-2010}
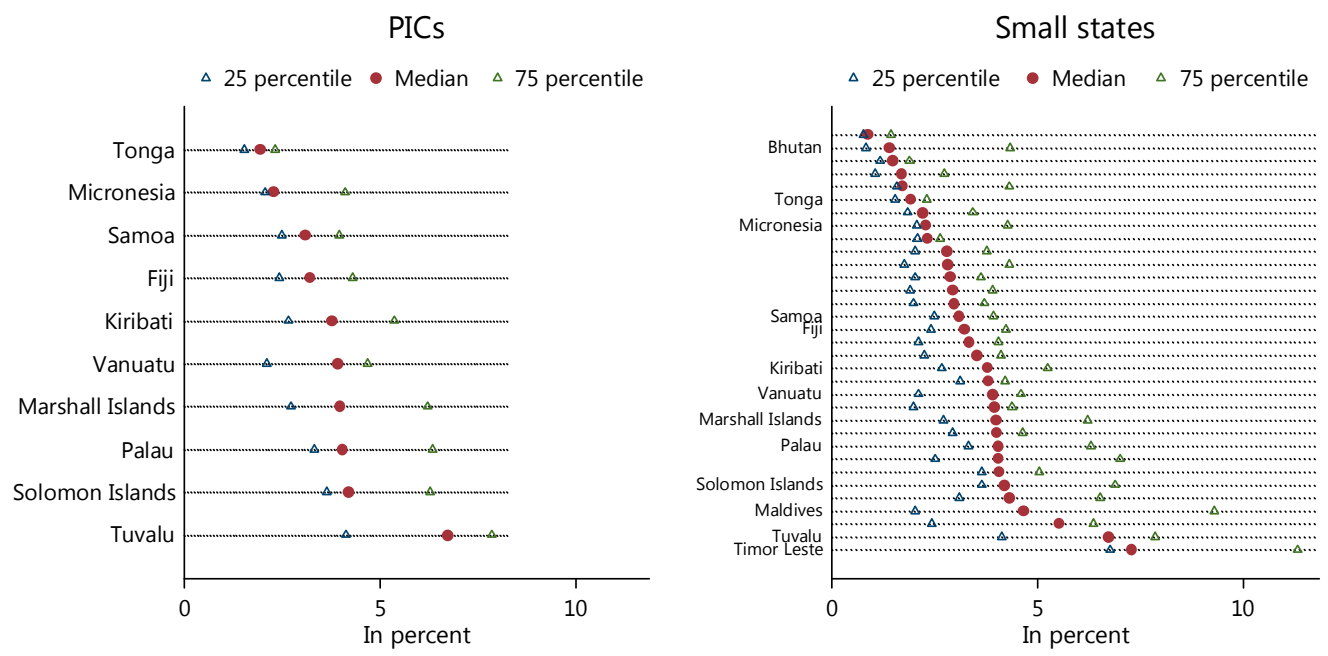

Sources: World Bank, WDI; IMF, WEO; and IMF staff calculations.

Figure 27. Small States-Asia and Pacific Region: Real per Capita GDP Volatility and Growth, 1990-2010

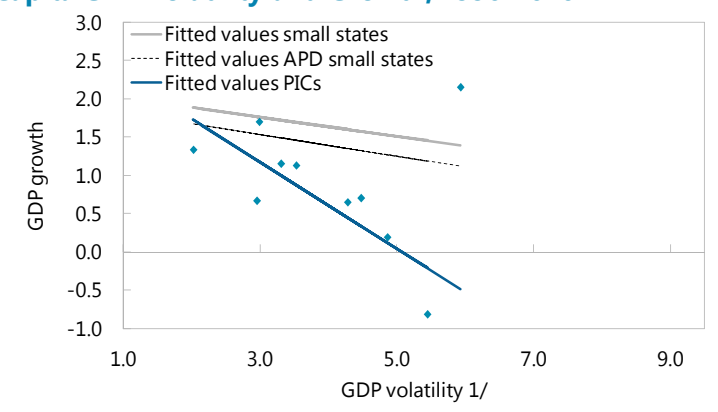

Sources: World Bank, WDI; IMF, WEO; and IMF staff calculations.

$1 /$ Volatility measured as the five-year backward looking standard deviation of real per capita GDP growth.
Figure 28. Small States-Asia and Pacific Region: Volatility of Real per Capita GDP Growth and Governance, 1990-2010

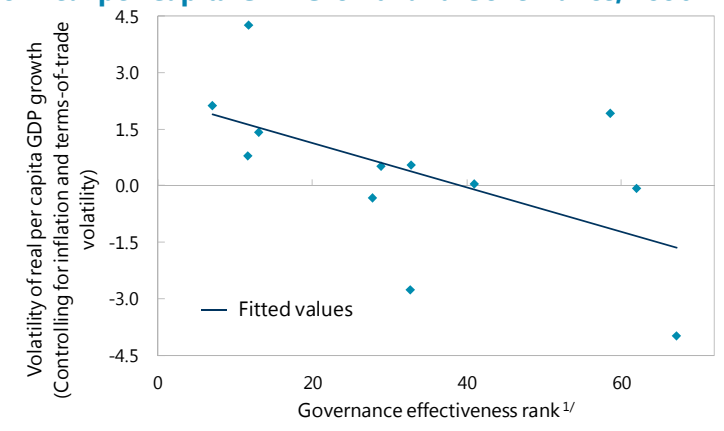

Sources: World Bank, Governance Indicators; and IMF staff calculations. $1 /$ Small values represent a low level of government effectiveness.

- Terms of trade, aid, and current account balance volatility (Figure 29). During 19902010, the terms of trade were more volatile than in other small states. Aid flows were also more volatile, especially among the micro states. Over the last 20 years, this volatility reflected a drop in assistance from traditional European donors, and the emergence of Australia as the largest aid provider in the Pacific. In the micro states, the greater aid volatility may also reflect the fact that aid flows generally finance specific one-off projects. Volatility of terms of trade and aid has resulted in greater current account volatility. 


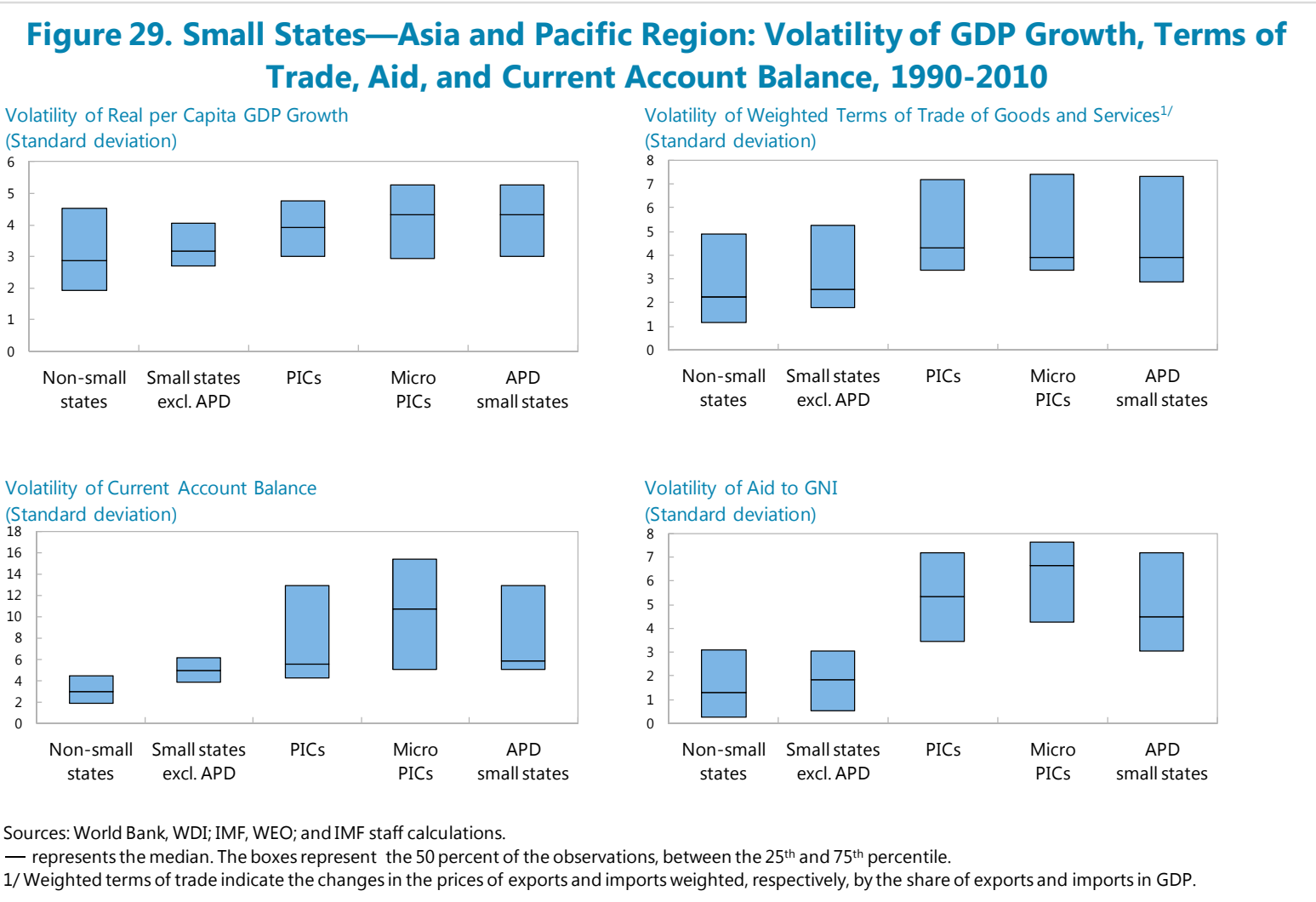

- Revenue volatility (Figures 30,31, and 32). Revenue volatility is higher in the Asia and Pacific small states - especially the micro states - relative to other small states (Box 1). The main source of volatility in micro states is non-tax revenues - particularly fishing license fees-which represent about 40 percent of revenues in micro states. Managing revenue volatility is a major challenge for Asia and Pacific small states as such volatility can foster fiscal policy Figure 30. Small States-Asia and Pacific Region: Revenue Volatility

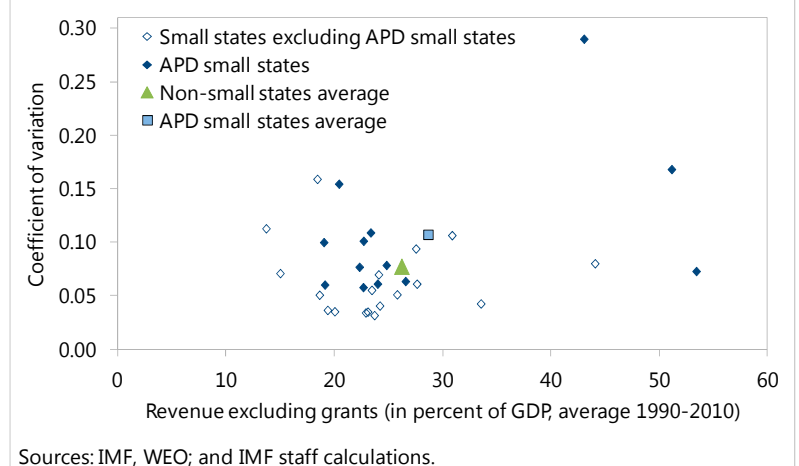
pro-cyclicality - that is, expansionary fiscal policy during upturns and contractionary policy during downturns. Indeed, fiscal policy appears to have been pro-cyclical in many Asia and Pacific small states in recent years. Only 5 out of 13 countries have adopted a multi-year budget framework to help smooth the expenditure path over the medium term. And only one country, Timor-Leste, has a fiscal rule and a stabilization fund to manage the volatility of fiscal revenue and ensure intergenerational equity in the distribution of earnings from its natural resources. 
Figure 31. Small States-Asia and Pacific Region: Fiscal Volatility, 1990-2010
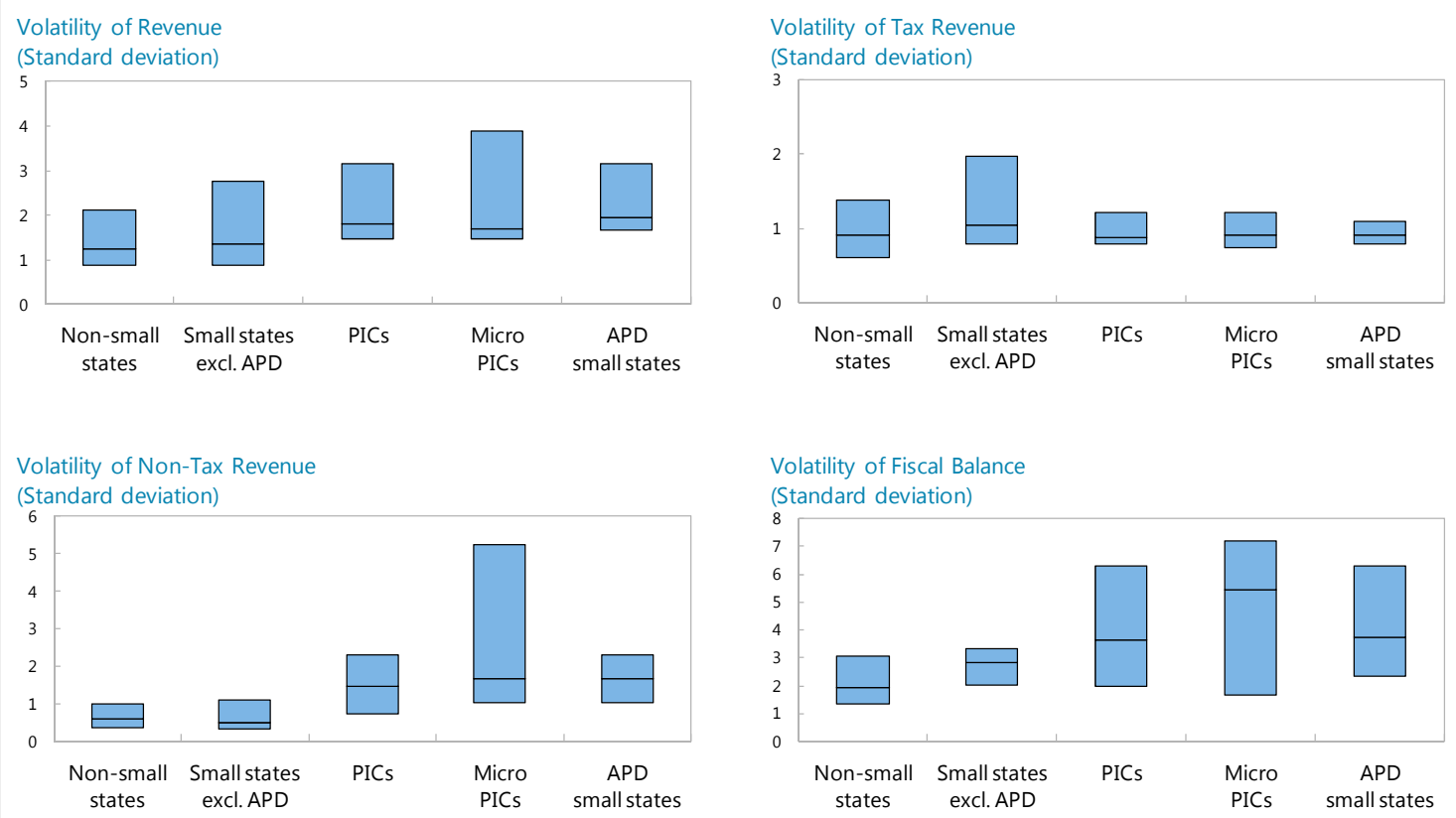

Sources: World Bank, WDI; IMF, WEO; and IMF staff calculations.

- represents the median. The boxes represent the 50 percent of the observations between the $25^{\text {th }}$ and $75^{\text {th }}$ percentile.

Figure 32. Small States-Asia and Pacific Region: Pro-cyclical Bias in Fiscal Policy, 2005-10
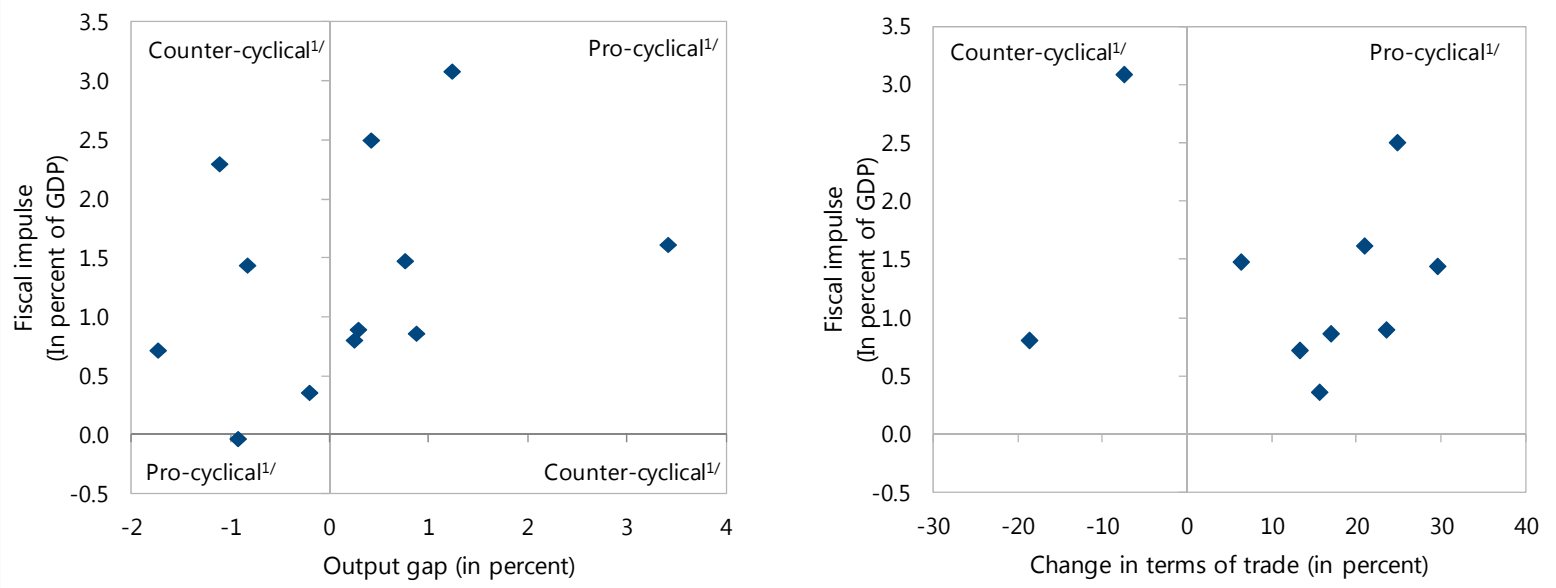

Source: IMF staff calculations, based on IMF, WEO.

1 / Indicates quadrants. 


\section{Box 1. Special Challenges Facing Pacific Islands Micro States}

More volatility. Micro states face more volatility with respect to their GDP growth, revenue, aid, terms of trade, and current accounts relative to the rest of the Asia-Pacific small states ${ }^{1}$ and other small states outside the region.

Climate change. Rising sea level is a large threat for Kiribati, Marshall Islands, and Tuvalu. The costs of climate change cannot be internalized by individual countries. And development spending is sometimes redirected to building sea walls. Aid for climate-change mitigation is expected to come at the expense of other project-financing aid, unless the aid envelope expands substantiallywhich does not appear likely.

High aid dependency. The micro states depend heavily on aid to finance their large external and internal imbalances, and their development needs. The expiration of the "Compact grants" in fiscal year 2023/24 would create both fiscal and external difficulties for Marshall Islands, Micronesia, and Palau if they fail to implement reforms to achieve self-sufficiency.

Fragility. Kiribati, Marshall Islands, and Micronesia are also classified as fragile states by the World Bank. ${ }^{2}$

http://web.worldbank.org/WBSITE/EXTERNAL/PROJECTS/STRATEGIES/EXTLICUS/0,,conte ntMDK:22230573 pagePK:64171531 menuPK:4448982 piPK:64171507 theSitePK:511778,00.h $\underline{\operatorname{tml}}$

1/ This is consistent with Colmer and Wood, 2012.

2/ The other fragile Asia and Pacific small states are Solomon Islands and Timor-Leste.

\section{Understanding Growth and Performance}

As a result of these factors, PICs' real GDP per capita is among the lowest among the small states (Figure 33). Since 1990, real GDP per capita (in PPP terms) in the PICs has increased less than 25 percent, compared with 45 percent in the Eastern Caribbean Currency Union (ECCU) and more than 30 percent in small states. PICs have not been able to benefit from growth in emerging Asia-where GDP has increased by about 120 percent over the same period.

Data on income per capita show a similar pattern (Figure 34). During 1990-2010, per capita income (in PPP terms) in the Pacific grew by 77 percent, compared with 130 percent in the ECCU and less than 85 percent in the small states. Per capita income in emerging Asia had grown by over 250 percent over the same period.

As of 2011, the average GNI per capita for the PICs was one third the average income of the Caribbean countries. While per capita GNI in Tuvalu and, to a lesser extent, in Marshall Islands and Micronesia, appears relatively high, it overstates public spending capacity in these countries. In Tuvalu, for example, GNI exceeds GDP by 60 percent, 
because of sizable government investment income from its sovereign trust fund whose assets are invested abroad. ${ }^{8}$ In Tuvalu, however, much of the investment income cannot be spent as the multilateral agreement governing the fund stipulates that the real value of the Trust Fund, indexed to Australian inflation, be maintained. This places limits on the use of earnings for budget support. The inflation component of earnings is about two-third of total earnings, or about 10 percent of GNI, which is the amount needed every year to maintain the value of the fund constant in real terms. Marshall Islands and Micronesia are bound by a similar bilateral agreement with the United States governing the trust fund management until 2023/24.

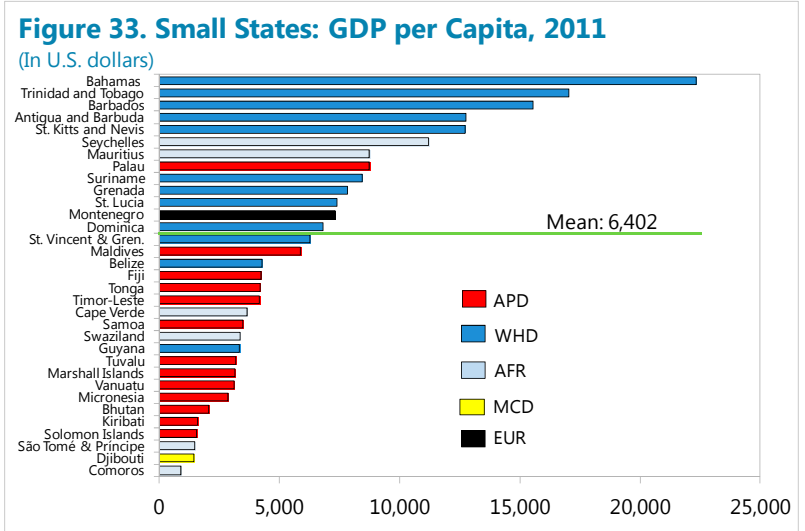

Sources: World Bank, WDI; and IMF, WEO.

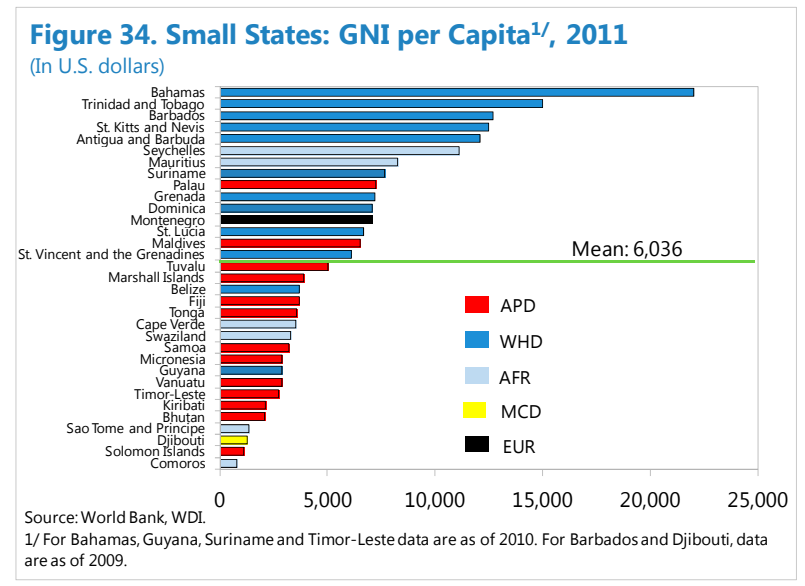

PICs seem to be stuck on a low-growth path. Growth in these countries has been weak over the last two decades, even more so relative to other small states (Figures 35 and 36). Over the last 20 years, PICs' annual GDP growth has averaged just 2 percent - much lower than the Asian low-income countries ( 6 percent), the ECCU countries ( 4 percent), and the small states ( $4 \frac{1}{2}$ percent). Because of their demographics, the underperformance of the PICs, in per capita terms, is also more striking.

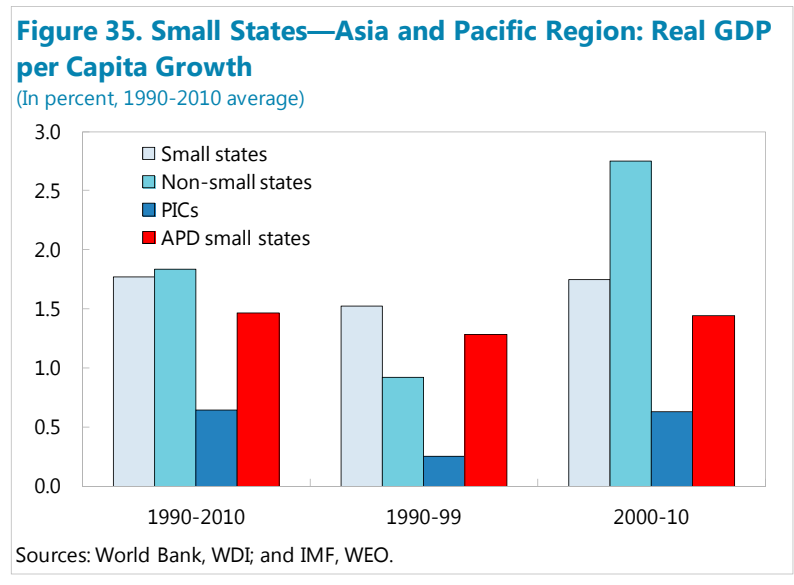

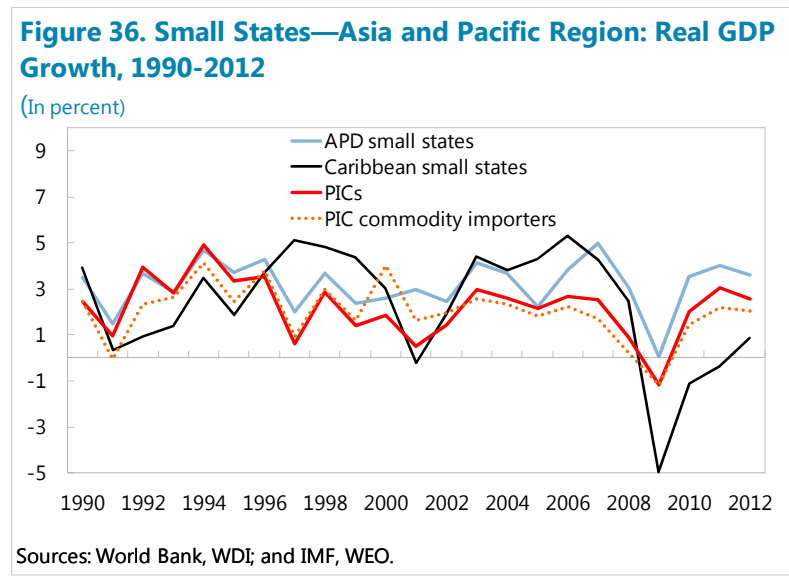

\footnotetext{
${ }^{8}$ In Tuvalu, the trust fund was established in 1987, by several development partners. The trust funds of Micronesia and of Marshall Islands were both established by the amended Compact Agreement between the United States and these countries in 2004.
} 
While the PICs have done slightly better than comparators during the recent business cycle, growth rates remain quite low, especially among the net commodity importers. Strong linkages with resilient economies in the region (Australia and, to a lesser extent, emerging Asia) have helped cushion the downturn in all PICs.

Since the 2008-09 crises, some Asia and Pacific small states have made progress in rebuilding policy buffers but they need to do more (Figure 37 ). Their reserve position has improved on balance relative to 2004-07. But more than half of the PICs emerged from the crisis with somewhat less comfortable fiscal buffers (higher debt and larger fiscal deficits) than before the crisis.

\section{A. Econometric Analysis: Growth Determinants in the Asia and Pacific Small States}

Our econometric analysis confirms that PICs have underperformed relative to their peers (Table 4). After controlling for some standard variables that explain per capita GDP growth, PICs suffer a disadvantage in per capita GDP growth of about 2 percentage points, compared with an average small state.

All variables have the expected sign. Trade openness and a well educated population have a positive impact on real GDP per capita growth, while public debt, GDP volatility, and government consumption do not. High government consumption crowds out productive investment. Our analysis shows that while small states have grown 11/4 percentage points less than big states (Model 1), after controlling for other variables, PICs have grown by 3 percentage points less than non-small states (Model 2).

Our econometric results show that PICs' geographical disadvantage undermines their growth performance. Once distance is included in the regression, the dummies for the PICs and other small states become insignificant (Model 5). This suggests that distance is a key variable in explaining the difference in growth performance in small states-especially the PICs - even after controlling for other factors. Remoteness is proxied by distance to the closest continent and the coefficient has the expected negative sign. This result is in line with other studies (Yang and others 2013). The APD small states as a whole have also underperformed relative to the average small states, but this difference is not statistically significant (Models 3 and 6). Finally, higher fixed government costs, capacity constraints, less openness, and higher GDP volatility relative to other small states also contribute to explain the difference in growth performance. 


\section{Figure 37. Small States-Asia and Pacific Region: Rebuilding Policy Buffers}
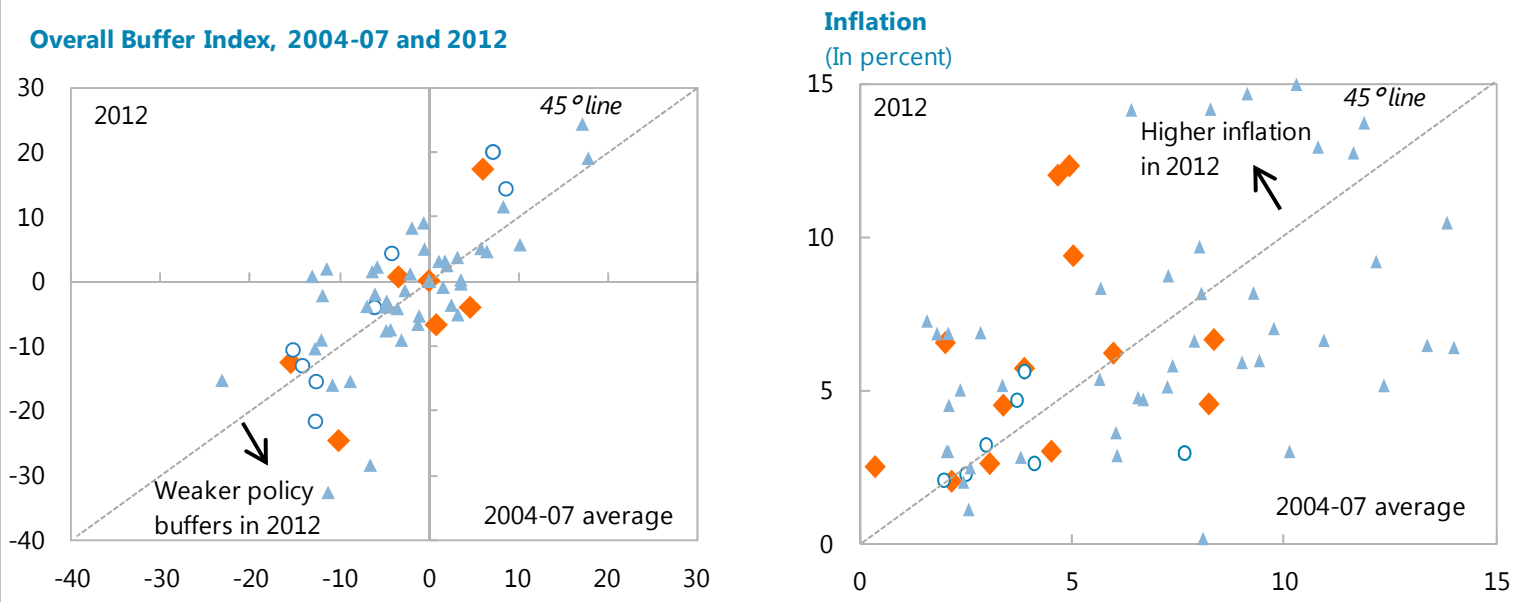

Fiscal Balance

(In percent of GDP)

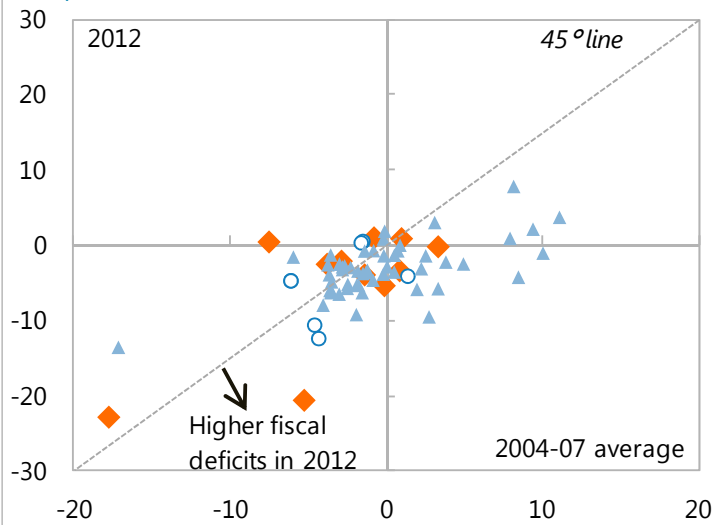

Current Account plus FDI

(In percent of GDP)

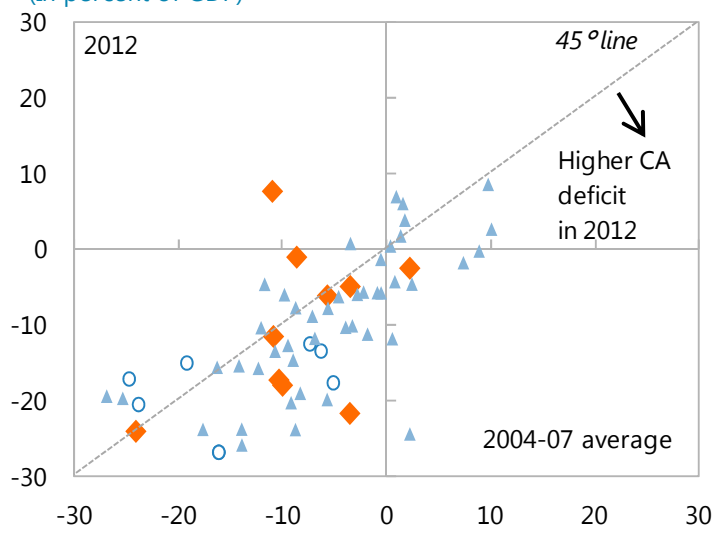

Gross Debt

Reserves

(In percent of GDP)

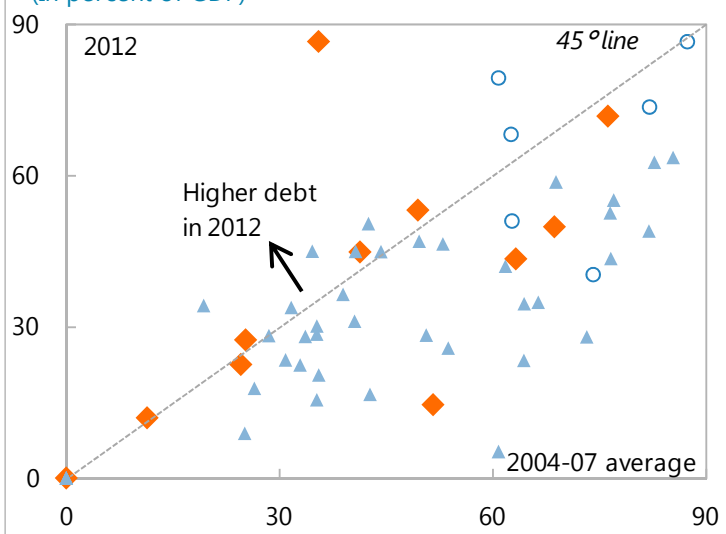

(In months of imports of goods and services)

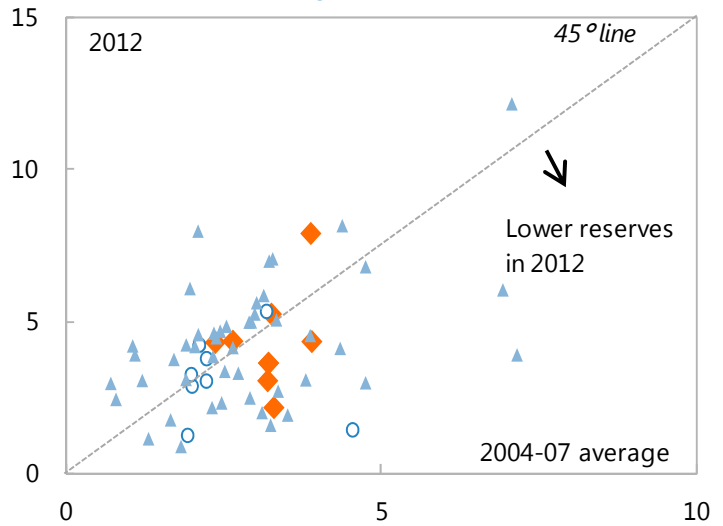

Note: Diamonds indicate Asia-Pacific small states; circles indicate non-Asia-Pacific small states; triangles are non-Asia-Pacific low-income countries. Based on the same methodology as in IMF, 2010.

Sources: Country authorities; and IMF staff calculations. 


\begin{tabular}{|c|c|c|c|c|c|c|}
\hline & Model 1 & Model 2 & Model 3 & Model 4 & Model 5 & Model 6 \\
\hline Small states & $-0.0126^{\star * \star}$ & $-0.0098^{* *}$ & $-0.0105^{\star *}$ & $-0.0084^{*}$ & -0.0070 & -0.0066 \\
\hline PICs & $\ldots$ & $-0.0197^{\star *}$ & $\ldots$ & $\ldots$ & -0.0161 & $\ldots$ \\
\hline APD small states & $\ldots$ & $\ldots$ & -0.0111 & $\ldots$ & $\ldots$ & -0.010 \\
\hline Oil exporter & $-0.0150^{\star \star}$ & $-0.0149 * * *$ & $-0.0150^{\star * *}$ & $-0.0167^{\star \star \star}$ & $-0.0163^{\star * *}$ & $-0.016^{\star \star \star}$ \\
\hline OECD & $-0.0094^{\star *}$ & $-0.0094^{\star *}$ & $-0.0095^{\star *}$ & $-0.0085^{*}$ & $-0.0087^{*}$ & $-0.0087^{\star *}$ \\
\hline Openness & $0.0084^{\star * *}$ & $0.0079 * * *$ & $0.0081^{\star * *}$ & $0.0085^{\star * *}$ & $0.0081^{\star * *}$ & $0.0082^{\star \star \star}$ \\
\hline Initial per capita GDP & $-0.0017^{\star \star \star}$ & $-0.0018^{\star \star \star}$ & $-0.0018^{\star \star \star}$ & $-0.0017^{\star \star \star}$ & $-0.0018^{\star \star \star}$ & $-0.0017^{\star \star \star}$ \\
\hline GDP volatility & $-0.4184^{\star \star \star}$ & $-0.4160 * \star \star$ & $-04178^{* * *}$ & $-04206^{\star * *}$ & $-0.4183^{* * *}$ & $-0.4200^{\star \star \star}$ \\
\hline Education & 0.0064 & 0.0042 & 0.0054 & 0.0086 & 0.0064 & 0.0077 \\
\hline Debt to GDP & $-0.0089 * * *$ & $-0.0092^{\star * \star}$ & $-0.0091^{\star \star \star}$ & $-0.0088^{\star * \star}$ & $-0.0092^{\star \star \star}$ & $-0.0090^{\star * \star}$ \\
\hline Government consumption to GDP & $-0.0913^{* * *}$ & $-0.0811^{\star \star *}$ & $-0.0876^{* * *}$ & $-0.0939 * * *$ & $-0.0852^{\star * \star}$ & $-0.0905^{\star \star \star}$ \\
\hline Distance & $\ldots$ & $\ldots$ & $\cdots$ & $-0.0011^{*}$ & -0.0009 & $-0.0011^{*}$ \\
\hline Constant & $0.0565^{\star * *}$ & $0.0583^{\star * \star}$ & $0.0574^{\star * *}$ & $0.0575^{\star * *}$ & $0.0587^{\star * \star}$ & $0.0581^{\star \star \star}$ \\
\hline Observations & 1,741 & 1,741 & 1,741 & 1,741 & 1,741 & 1,741 \\
\hline
\end{tabular}

\section{Further econometric analysis shows that indeed APD small states are different from} other small states. In order to quantify the importance of different growth determinants of the Pacific islands relative to comparators, we regressed each explanatory variable used in Table 4 on the same set of regional dummy variables as well as on the dummies for small states and PICs. Compared with an average small state, PICs have lower initial income, less openness, lower education, lower debt, but have higher GDP volatility, and higher government consumption, as expressed by the sign of the coefficients of the PIC dummy in Table 5. Combining the results of Table 4 and Table 5, we can disentangle the relative impact of each determinant in explaining growth in the PICs relative to other small states. For example, PICs lower initial income has a positive effect on growth. Based on the convergence hypothesis we found in the regression, the lower initial income has allowed PICs to grow about $1 / 2$ percentage point $(=-2.3 *-0.0017)$ faster than an average small state. However, this positive factor, together with PICs lower debt level relative to other small states which has increased PICs' growth by about 0.1 percentage point $\left(=-0.113^{*}-0.0088\right)$, have been negatively offset by others (lower education, higher distance, higher government consumption over GDP, lower openness and high GDP volatility) that have been detrimental to PICs' growth performance. For example, higher government consumption relative to GDP has a large negative growth effect for the PICs $\left(0.167^{*}-0.0939=-1.6\right.$ percentage points $)$. The same exercise was performed for all APD small states (Table 6). 
Table 5. Pacific Islands Countries: Growth Advantages and Disadvantages $1 /$

\begin{tabular}{|c|c|c|c|c|c|c|c|}
\hline Dependent Variable & $\begin{array}{c}\text { Initial real per- } \\
\text { capita GDP }\end{array}$ & $\begin{array}{c}\text { GDP } \\
\text { volatility }\end{array}$ & Openness & Education & $\begin{array}{l}\text { Debt to } \\
\text { GDP }\end{array}$ & $\begin{array}{l}\text { Government } \\
\text { Consumption } \\
\text { to GDP }\end{array}$ & Distance \\
\hline PICs & -2.303 & 0.001 & -0.279 & -0.130 & -0.113 & 0.167 & 3.102 \\
\hline Small states & -0.086 & -0.002 & 0.356 & 0.180 & 0.009 & 0.048 & 3.182 \\
\hline
\end{tabular}

1/ All regressions include a full set of regional dummies, dummies for OECD and oil exporters.

Table 6. Small States-Asia and Pacific Region: Growth Advantages and Disadvantages of 1/

\begin{tabular}{|c|c|c|c|c|c|c|c|}
\hline Dependent Variable & $\begin{array}{c}\text { Initial real per- } \\
\text { capita GDP }\end{array}$ & $\begin{array}{c}\text { GDP } \\
\text { volatility }\end{array}$ & Openness & Education & $\begin{array}{l}\text { Debt to } \\
\text { GDP }\end{array}$ & $\begin{array}{l}\text { Government } \\
\text { Consumption } \\
\text { to GDP }\end{array}$ & Distance \\
\hline APD Small States & -1.820 & 0.002 & -0.403 & -0.140 & -0.223 & 0.156 & 2.098 \\
\hline Small states & -0.094 & -0.002 & 0.422 & 0.193 & 0.052 & 0.037 & 3.144 \\
\hline
\end{tabular}

1/ All regressions include a full set of regional dummies, dummies for OECD and oil exporters.

\section{Policy Implications: How to Raise Growth Potential and Enhance RESILIENCE}

\section{Decisive policy measures by Asia-Pacific small state governments can go a long way toward addressing the challenges they face. Given their high vulnerability to external shocks and still low potential growth, these countries should continue rebuilding policy buffers in a way that reinforces efforts to implement growth-enhancing reforms:}

- $\quad$ Strengthening domestic revenue mobilization would support the rebuilding of policy buffers. Revenue compliance is extremely challenging to enforce, especially in islands that are widely scattered. Further progress in strengthening revenue collection, including by streamlining and simplifying existing tax and customs regimes with technical assistance provided by development partners, would also help create fiscal space to meet critical development spending needs.

- Improving the composition of public spending with regard to education, health, and infrastructure would be key to fostering inclusive growth. Public investment in infrastructure could help crowd-in private investment, thereby promoting more broadbased growth, including by attracting FDI and stimulating more tourism. Increasing investment in education would also raise potential growth.

- Sound structural policies can enhance long-term resilience to shocks and boost growth potential. Implementing growth-oriented structural reforms that enhance the business environment can boost investor confidence and private-sector growth. The Asia and 
Pacific small states have enormous untapped marine resources and further effort is needed to properly exploit and manage them.

- Strengthening institutions and improving governance should be a key part of governments ' reform agenda and of development partners' capacity-building programs. Bolstering public institutions, particularly through public finance management reforms, would also improve expenditure efficiency. Strengthening public finance by introducing a multi-year budget framework will help bring about realistic fiscal plans and guard against pro-cyclical policies. A multi-year fiscal framework built around simple fiscal anchors could also contribute to a better balance between rebuilding buffers and allocating sufficient budget resources for priority needs. From a political economy point of view, this would also help build consensus on the appropriate sequencing of development projects and contain spending pressure in the near term. This would also help better calibrate the pace of spending by taking into account capacity constraints.

\section{Some scope exists for increasing competition in the banking sector, but financial deepening also requires the development of non-bank institutions. These include finance companies, foreign exchange dealers, and micro-credit institutions, which have the potential to be competitive, apart from the main commercial banks. Financial-inclusion initiatives, such as lowering the cost of remittances and mobile phone banking, can also help foster private sector development.}

Regional solutions to common problems should also continue to be pursued. A regional approach can help individual countries mitigate the challenges associated with their small size and high dispersion, including by increasing economies of scale through cooperation. Regional approaches can encourage the alignment of regulations and laws across the Pacific, lower transaction costs, and reduce the need for country-specific knowledge on regulatory approaches. They can also promote regional integration and the exchange of knowledge, best practices, and experience. Regional solutions to natural disaster risk insurance could be pursued. ${ }^{9}$ The key sectors include fisheries, information and communication technology, and aviation safety. Progress has been made in the fishery sector, through the Nauru Agreement, to strengthen regional capacity to increase bargaining power of license-issuing countries, and regional control to stop illegal fishing, but major barriers to labor and investment persist and require further collective efforts. The seasonal employment scheme, opened to PICs and Timor-Leste, first introduced by New Zealand in 2006 and followed more recently by Australia is a successful case of enhanced integration with neighboring countries that has generated income opportunities and enhanced skills of Pacific island workers in countries with a shortage of labor.

\footnotetext{
${ }^{9}$ In January 2013, Japan, the World Bank, and the Secretariat of the Pacific Community teamed up with Pacific Island Countries to launch the Pacific Catastrophe Risk Insurance Pilot.
} 
Further integration with the Asia and Pacific region, through trade and investment, should help raise growth potential. While the Pacific islands are geographically scattered and remote, the closest markets are the most dynamic in the world. The resilience of Australia and emerging Asia in recent years has played an important role in helping the Pacific Islands' recovery. 


\section{REFERENCES}

Asian Development Bank, 2012, Key Indicators for Asia and the Pacific, http://www.adb.org/publications/key-indicators-asia-and-pacific-2012.

Becker, Chris, 2012, "Small Island States in the Pacific: the Tyranny of Distance?" IMF Working Paper No. 12/223.

Briguglio, Lino, 1995, "Small Island Developing States and Their Economic Vulnerabilities," World Development, Vol. 23, No. 9.

Browne, Christopher, 1988, Economic Development in Seven Pacific Island Countries, International Monetary Fund.

Browne, Christopher, 2006, Pacific Island Economies, International Monetary Fund.

Colmer, Patrick, and Richard Wood, 2012, "Major Economic Shocks and Pacific Island Countries," www.imf.org/external/np/seminars/eng/2012/PIC/pdf/tre.pdf.

Davies, Matt, and John Vaught, 2011, Interest Rates and Bank Profitability in the South Pacific, www.pftac.org/filemanager/files/Regional.../Governors_Paper.pdf.

Easterly, William, and Aart Kraay, 2000, "Small States, Small Problems? Income, Growth and Volatility in Small States," World Development, 28 (11).

Gibson, John, and Karen Nero, 2007, “Are Pacific Island Economies Growth Failures? GeoPolitical Assessments and Perspectives" Pasifika Series Working Papers, Department of Economics, University of Waikato, 2007.

Haque, Tobias, David Knight, and Dinuk Jayasuriya, 2012, "Capacity Constraints and Public Financial Management in Small Pacific Island Countries,” PRWP, No. 6297, World Bank.

International Monetary Fund, 2010, "Emerging from the Global Crisis: Macroeconomic Challenges Facing Low-Income Countries," www.imf.org/external/np/pp/eng/2010/100510.pdf.

International Monetary Fund, 2013, "Macroeconomic Issues in Small States and Implications for Fund Engagement," www.imf.org/external/np/pp/eng/2013/022013.pdf.

International Monetary Fund, 2013, "Caribbean Small States: Challenges of High Debt and Low Growth,” www.imf.org/external/np/pp/eng/2013/022013b.pdf.

International Monetary Fund, 2013, "Lifting Potential Growth in the Pacific Islands: Structural Impediments and the Role of Policies," in Regional Economic Outlook: Asia and Pacific: Shifting Risks, New Foundations for Growth, Box 1.10, http://www.imf.org/external/pubs/ft/reo/2013/APD/eng/c1 0413.pdf. 
Marshall, Monty, and Keith Jaggers, 2009, Polity IV Project: Political Regime Characteristics and Transitions, 1800-2007-Dataset Users' Manual (Arlington, Virginia: Polity IV Project).

Paul Cashin and Norman Loayza, 1995, "Paradise Lost? Growth, Convergence, and Migration in the South Pacific", IMF Staff Papers, Vol. 42, pp. 608-41.

Sheridan, Niamh, Patrizia Tumbarello, and Yiqun Wu, 2012, "Global and Regional Spillovers to Pacific Island Countries,” IMF Working Paper No. 12/154.

World Bank, 2012, Acting Today for Tomorrow, A Policy and Practice Note for Climate and Disaster Resilient Development in the Pacific Islands Region, http://www.worldbank.org/en/news/2012/06/04/acting-today-for-tomorrow-a-policyand-practice-note-for-climate-and-disaster-resilient-development-in-the-pacificislands-region.

World Bank, 2013, Business Indicators, Smarter Regulations for Small and Medium-Size Enterprises, http://www.doingbusiness.org/reports/global-reports/doing-business2013.

Yang, Yongzheng, Matt Davies, Shengzu Wang, Jonathan Dunn, and Yiqun Wu, 2011, "Monetary Policy Transmission Mechanisms in Pacific Island Countries," IMF Working Paper No. 11/96.

Yang, Yongzheng, Hong Chen, Shiu Raj Singh, and Baljeet Singh, 2013, “The Pacific Speed of Growth: How Fast Can It Be and What Determines It?” IMF Working Paper No. $13 / 104$. 
Appendix Table-Small States of the Asia and Pacific Region: Selected Indicators, $2012^{1 /}$

\begin{tabular}{|c|c|c|c|c|c|c|c|c|c|c|c|c|}
\hline & $\begin{array}{c}\text { GDP } \\
\text { (In US\$ } \\
\text { billions) }\end{array}$ & $\begin{array}{c}\text { Population } \\
\text { (In thousands) }\end{array}$ & $\begin{array}{c}\text { Sea area } \\
\left(\text { In } \mathrm{km}^{2}\right)\end{array}$ & $\begin{array}{l}\text { Land area } \\
\left.\text { (In } \mathrm{km}^{2}\right)\end{array}$ & $\begin{array}{c}\text { GDP } \\
\text { Per Capita } \\
\text { (Current US\$) }\end{array}$ & $\begin{array}{l}\text { Real GDP } \\
\text { Growth } \\
\text { (In percent) }\end{array}$ & $\begin{array}{c}\text { CPI } \\
\text { Inflation }^{2 /} \\
\text { (In percent) }\end{array}$ & $\begin{array}{c}\text { Current } \\
\text { Account }^{3 /}\end{array}$ & $\begin{array}{c}\text { Fiscal } \\
\text { Balance }^{3 /}\end{array}$ & $\begin{array}{c}\text { Gross Public } \\
\text { Debt }^{3 /}\end{array}$ & Reserves $^{3 /}$ & Openness $^{4 /}$ \\
\hline Bhutan & 1.90 & 743 & 0 & 38,394 & 2,556 & 9.7 & 13.0 & -21.9 & -4.0 & 66.1 & 41.2 & 103.6 \\
\hline Maldives & 2.22 & 420 & 923,322 & 300 & 5,273 & 3.4 & 8.0 & -27.1 & -12.6 & 73.3 & 13.7 & 206.3 \\
\hline Timor-Leste & 4.21 & 1,119 & 70,326 & 14,874 & 3,766 & 10.0 & 11.1 & 45.4 & 39.9 & 1.0 & 19.4 & $40.5^{5 /}$ \\
\hline \multicolumn{13}{|l|}{ Pacific Island Countries } \\
\hline Fiji & 4.02 & 899 & $1,290,000$ & 18,272 & 4,475 & 2.4 & 3.5 & -8.6 & -1.6 & 51.5 & 22.2 & 115.0 \\
\hline Kiribati & 0.18 & 106 & $3,550,000$ & 810 & 1,653 & 2.5 & 3.0 & -17.6 & -21.8 & 40.0 & $\ldots$ & 104.5 \\
\hline Marshall Islands & 0.18 & 53 & $2,131,000$ & 181 & 3,432 & 1.9 & 5.7 & -6.3 & -1.1 & 57.2 & $\ldots$ & 134.5 \\
\hline Micronesia & 0.33 & 103 & $2,978,000$ & 701 & 3,185 & 1.4 & 5.6 & -15.0 & 1.2 & 26.6 & $\ldots$ & 102.4 \\
\hline Palau & 0.23 & 21 & 629,000 & 494 & 11,183 & 4.0 & 1.7 & 7.7 & -2.5 & 34.2 & $\ldots$ & 156.6 \\
\hline Samoa & 0.68 & 189 & 120,000 & 2,935 & 3,603 & 1.3 & 5.5 & -9.9 & -5.6 & 80.3 & 23.1 & 96.8 \\
\hline Solomon Islands & 1.01 & 565 & $1,340,000$ & 28,370 & 1,786 & 5.5 & 6.2 & -10.5 & -0.6 & 18.2 & 49.9 & 125.7 \\
\hline Tonga & 0.47 & 103 & 700,000 & 699 & 4,557 & 0.8 & 2.5 & -3.8 & -3.0 & 45.7 & 29.9 & 67.3 \\
\hline Tuvalu & 0.04 & 11 & 900,000 & 26 & 3,246 & 1.2 & 3.5 & -8.6 & 4.3 & 43.4 & $\ldots$ & 132.4 \\
\hline Vanuatu & 0.76 & 250 & 710,000 & 12,190 & 3,039 & 2.6 & 2.2 & -6.1 & -3.4 & 22.5 & 23.9 & 103.1 \\
\hline \multicolumn{13}{|l|}{ Memorandum Items: } \\
\hline Frontier and low-income Asia ${ }^{6,7 /}$ & 376 & 385,853 & $\ldots$ & $\ldots$ & 1,160 & 6.4 & 6.2 & -7.0 & -3.9 & 33.3 & 14.0 & 110.5 \\
\hline Emerging Asia ${ }^{6,8 /}$ & 14,160 & $3,098,677$ & $\ldots$ & $\ldots$ & 8,336 & 4.6 & 3.8 & 2.6 & -1.7 & 40.1 & 45.2 & 130.7 \\
\hline
\end{tabular}

Sources: IMF, WEO; and APD low-income countries database.

1/ Preliminary estimates.

2/ End of the period.

3/ In percent of GDP.

4/ Exports plus imports of goods and services as a percent of GDP.

5/ Excludes oil exports, which are recorded as income in the balance of payments.

$6 /$ Total for GDP and population. Median for the rest of the variables.

7/ Includes Bangladesh, Cambodia, Lao People's Democratic Republic, Mongolia, Myanmar, Nepal, Papua New Guinea, and Vietnam.

8/ Includes China, Hong Kong SAR, India, Indonesia, Korea, Malaysia, Philippines, Singapore, and Taiwan Province of China. 